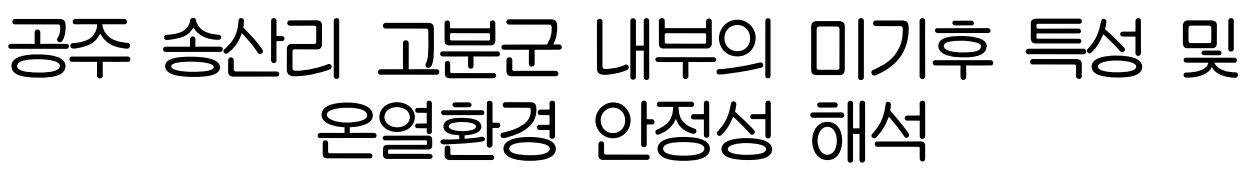

김성한 | 이찬희 ${ }^{1}$

공주대학교 문화재보존과학과

\title{
Interpretation on Internal Microclimatic Characteristics and Thermal Environment Stability of the Royal Tombs at Songsanri in Gongju, Korea
}

\author{
Sung Han Kim I Chan Hee Lee \\ Department of Cultural Heritage Conservation Sciences, Kongju National University, Gongju, 32588, Korea \\ ${ }^{1}$ Corresponding Author: chanlee@kongju.ac.kr, +82-41-850-8543
}

\begin{abstract}
초 록 송산리 고분군은 한반도 고대사 연구에 가장 중요한 유적의 하나이나, 발굴 이후 지속적인 외부환경 노출과 인위적 공조시스템의 부작용으로 고분의 온열환경 안정성에 상당한 위협이 초래되었다. 고분군의 현실은 계절변화에 따라 큰 차이가 나타나는 외부 기온과는 달리 연중 $11.4 ~ 22.2^{\circ} \mathrm{C}$ 의 비교적 안정적인 온도분포를 보였고, 표준편차도 3.5 이내로 나타났다. 고분의 미기후 환경에 영향을 미친 주요인은 외부 공기의 유입과 풍향 및 풍속으로, 이는 모두 고분군의 기밀성과 깊은 관련이 있다. 일사는 고분의 봉분두께와 반비례 관계를 보였으며, 봉분이 두꺼운 무령왕릉이 일사의 영향을 가장 적게 받았다. 특히 사람의 출입으로 인한 인위적 환경변화가 내부 환경의 안정성에 가장 큰 영향을 주었으며, 출입인원 및 재실시간에 비례하여 변화하는 특징을 보였다. 현재 송산리 고분군 내부는 밀폐되어 항상 포화상 태를 유지하고 있어 결로에 매우 취약한 상태이다. 고분별로 결로 발생 가능성을 분석한 결과, 5 호분과 6 호분 및 무령왕릉 모두 연중 대부분 결로가 발생하는 것으로 나타났다. 결로는 미생물의 생장을 돕고 부재를 이완시키므로 반드시 적절한 안정화 대책이 수립되어야 한다.
\end{abstract}

중심어: 송산리 고분군, 온열환경 안정성, 미기후 특성, 보존환경, 결로

ABSTRACT The Royal Tombs at Songsanri is one of the most important historic site for ancient historical study in Korean Peninsula. Since the excavation of the tombs, continuous exposure to the outside environment and the negative effects of the artificial air conditioning system have caused significant threats to the thermal environment stability of the tombs. Unlike the outside temperature that shows significant differences according to seasonal changes, the burial chamber of the tombs had a relatively stable temperature range of 11.4 to $22.2^{\circ} \mathrm{C}$ throughout the year, and the standard deviation of temperature was within 3.5. It was revealed that major factors affecting the microclimate of the tombs were inflow of outdoor air, wind direction and speed, and all of them had closely related to airtightness of the tombs. The solar radiation was in inverse proportion to the thickness of burial mounds, and thus Royal Tomb of King Muryeong, which has the thickest burial mound, was least affected by solar radiation. Especially, microclimate of the tombs caused to the highest influence with artificial environmental changes due to access by people, which varied in proportion to the number of 
accessed people and time of stay. Currently, the inside of the tombs are sealed and always in saturated condition, it is very vulnerable to dew condensation. As a result of analyzing the possibility of condensation in each tomb, all the tomb No. 5, tomb No. 6 and Royal Tomb of King Muryeong had condensation most of the time throughout the year. It is required to make a proper conservation environment for the Royal Tombs at Songsanri.

Key Words: Royal Tombs at Songsanri, Thermal environment stability, Microclimate characteristics, Conservation environment, Condensation

\section{1. 서 언}

1971년에 있었던 무령왕릉의 발굴은 백제문화 뿐만 아 니라 한반도 고대사 연구에 가장 큰 영향을 미친 역사적인 사건이었다. 무령왕릉 발굴과 함께 송산리 6 호분이 재조명 되었으며, 규모와 축조방식 및 벽화 등으로 보아 왕릉급 고 분으로 평가받게 되었다. 이러한 송산리 고분군은 탁월한 보편적 가치와 진정성 및 완전성을 인정받아 2015년 세계 문화유산으로 등재되었다. 그러나 고분들은 발굴 및 현실 개방으로 인해 안정상태가 손상되면서 수차례의 급격한 환 경변화를 겪었으며, 이를 제어하기 위해 가동한 공조시스 템의 부작용으로 내부의 불안정성이 증가하였다.

이 고분군은 공조시스템이 중단된 2011년부터 고습한 환경에 노출되어 있으며, 이를 올바르게 제어하고 안정적 인 보존환경을 조성하기 위한 다각적인 방안이 검토되었 다. 그러나 고분과 같이 고습한 환경을 유지하는 밀폐된 공 간에서 손상을 유발하지 않고 인위적으로 환경을 제어하는 것은 불가능에 가깝다. 인위적 공조의 대표적인 사례로 일 본의 다카마스카 고분과 프랑스의 라스코 동굴이 있으나, 이는 다양한 연구와 노력 및 예산 투입에도 불구하고 성공 을 거두지 못하였다.

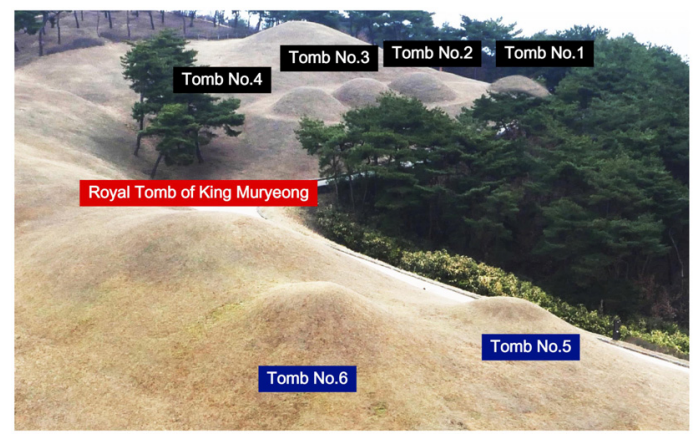

Figure 1. Field appearance of Royal Tombs at Songsanri in Gongju.
최근 송산리 6 호분에서도 연구사례를 바탕으로 친환경 적인 방식의 수동적(passive) 관리방안들이 제안되고 있으 며(Lee et al., 2014; Kim et al., 2016), 직접적인 자료와 경 험을 바탕으로 각 고분의 공간구조 성격에 적합한 보존환 경 조성에 관한 연구가 필요한 상태였다. 따라서 이 연구에 서는 송산리 고분군의 미기후 특성을 분석하고, 이에 영향 을 미치는 환경요인을 면밀히 검토하여 고분군의 현재 상 태와 보존환경을 정밀하게 기록하였다. 이 결과는 송산리 고분군의 성격에 적합한 최적의 보존환경을 구현하기 위한 기준과 자료로 활용할 수 있을 것이다.

\section{2. 연구대상 및 방법}

\section{1. 연구대상}

송산리 고분군은 백제 웅진도읍기에 재위한 왕과 왕족 의 무덤이 모여 있는 곳으로, 사적 제 13 호로 지정하여 관리 하고 있다. 이 고분군에는 약 20 여기 이상의 고분이 있었던 것으로 알려져 있으나, 현재는 무령왕릉을 포함한 총 7기 의 고분만이 표고 약 $120 \mathrm{~m}$ 의 송산을 주산으로 남쪽 경사 면에 보존되어 있다. 송산리 1 에서 4 호분은 계곡의 동북쪽 에 고분마다 $20 \mathrm{~m}$ 에서 $30 \mathrm{~m}$ 의 거리를 두고 일렬로 배치되 어 있고, 5 호분과 6 호분 및 무령왕릉은 계곡의 서쪽에 삼각 형 모양으로 하나의 그룹을 형성하고 있다(Figure 1).

이 연구의 대상은 송산리 5 호분과 6 호분 및 무령왕릉이 다. 5 호분은 한성도읍기 초기 형태인 궁륭형 천장을 가진 횡혈식석실분으로 형태가 일정하지 않은 할석을 이용하여 비규칙적으로 축조하였다. 일부 벽면과 바닥면은 회로 마 감하였으나, 현재는 부분적으로 흔적만 남아 있다. 6 호분 은 아치형 구조의 전축분으로 장방형 현실과 이중 연도로 구성하였으며, 현실의 네 벽에는 벽화를 조성하였다. 이 벽 화는 전축분의 벽면에 사신도를 그린 국내 유일의 사례로 주목받아 왔다. 
6호분의 배수로 공사 중에 발견한 무령왕릉은 처녀분으 로 발굴되면서 삼국시대 고분에서는 유일하게 피장자의 신 원과 고분의 축조연대가 확인되었다. 따라서 무령왕릉은 백제시대 고분문화와 편년연구의 기준이 되었으며, 당시의 정치상황과 국제관계 및 문화교류 등을 살펴볼 수 있는 매 우 귀중한 문화유산으로 평가받고 있다.

무령왕릉은 풍부한 부장품과 함께 완전한 형태로 발굴 되어 석수, 지석, 오수전과 더불어 당대의 정치와 경제, 문 화상을 복원할 수 있는 많은 정보가 담긴 중국제 자기, 무 령왕과 왕비의 장신구 및 각종 청동그릇 등 약 108 여 종 4,680점의 유물이 출토되었다(Lee, 2009). 또한 지석의 기 록을 통해 무령왕을 지시하는 백제 사마왕이 523년 5월에 사망하여 525년 8월에 안장되었다는 사실을 확인할 수 있 다(Figure 2A). 무령왕과 왕비의 관재는 일본의 금송을 사 용한 것으로 나타났는데(Figure $2 \mathrm{~B})$, 이는 당시 백제와 일 본의 관계를 추론할 수 있는 자료이다(Jung, 2009).

무령왕릉과 송산리 6호분은 백제 웅진도읍기의 주요 묘 제인 횡혈식석실분과는 다른 전축분이다. 이는 당시 중국 남조에서 유행하던 무덤양식으로 백제가 중국과도 밀접한 관계였음을 알 수 있다. 6호분은 도굴된 상태로 발견되어 피장자의 신원은 확인되지 않았으나, 축조재료, 제작시기 및 규모 등으로 보아 왕릉급 고분으로(Jung, 2011), 벽돌문 양 및 무령왕릉 출토 매지권을 통해 무령왕과 왕비의 초장 지로 추정되기도 하였다(Lee, 2017).

송산리 6호분은 무령왕릉과 많은 유사성에도 불구하고 내부 벽면에 벽화(사신도)가 있다(Figure $2 \mathrm{C}$ ). 이는 부여 능 산리 1호분(동하총)과 함께 백제시대 고분벽화의 드문 사 례라는 점에서 매우 중요하다. 이 벽화는 안료가 바탕에 스 며들게 하는 습지벽화법으로 제작되었으며, 특히 전축의 벽면 위에 조성된 전축회면화법으로 우리나라에서 유일한 사례이다(Yoon, 2008). 벽체는 오수전 문양의 벽돌을 이용
하여 아래서부터 10.8.6.4평1수의 방식을 취하고 있으며, 위로 올라갈수록 길이모쌓기 높이를 $20 \%$ 씩 줄여나갔다. 이와 같이 6 호분은 중국 남조의 기법을 계승하면서도 독자 적인 특징을 보여주는 예로 백제인의 창조적 역량도 엿볼 수 있는 고분이다(Yoon, 2008).

\section{2. 보존이력 및 현황}

송산리 고분군은 무령왕릉 발굴 이후, 전실 신축, 통로 및 석축시공, 봉분 조영 등의 대대적인 종합정비공사가 있 었고, 1973년부터는 고분 내부를 일반인에게 공개하기 시 작하였다. 전실에서 유리벽을 통해 현실을 관람할 수 있도 록 조치하였으며, 현실 내부로의 출입은 제한하였다. 그러 나 결로, 미생물 생장, 벽체거동 등 많은 문제점이 제기되 었고, 고분 내부로 누수가 발생하면서 1996년에는 1차 종 합정밀조사를 수행하였다(Suh et al., 1998).

이 결과, 고분개방과 출입이 훼손요인으로 밝혀지면서 1997년 다시 고분 내부를 영구적으로 폐쇄하였고(Figure $3 \mathrm{~A})$, 응급조치로 냉방기, 대형제습기, 온습도자동계측기 등을 설치하였다. 1999년에는 누수방지 강회다짐층 조사 및 보수, 봉분재조정 공사, 미생물 보존처리가 이루어졌으 며, 공사 전후의 변화를 모니터링하기 위해 2차 종합정밀 조사가 실시되었다(Suh et al., 2000).

제2차 정밀조사 결과를 바탕으로 2003년에는 각 고분의 전실에 항온항습기를 추가로 설치하였다. 덕트를 통해 현 실로 공기를 보내는 방식으로 설계되었으나, 고분의 보존 에 큰 도움이 되지 않았고, 오히려 벽체와 6 호분의 벽화를 건조시켜 손상을 유발하는 것으로 판단하여 2011년 모든 항온항습기의 가동을 중단하였다. 이후 2012년에는 벽화 의 응급보존처리가 수행되었으며, 고분의 효과적인 보존환 경과 항구적인 안전체계를 구축하기 위한 연구가 진행되었
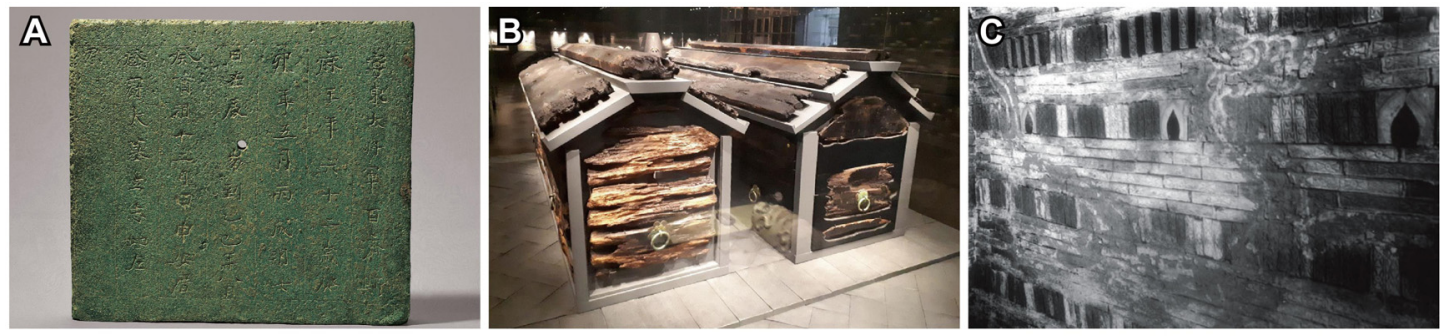

Figure 2. Historical significance of Royal Tombs at Songsanri in Gongju. (A) Memorial stone of the Royal Tomb of King Muryeong, (B) Replica coffins of the king and queen, (C) Status of the mural on eastern wall of Songsanri tomb No. 6 in 1933(Jung, 2012). 
다(Lee et al., 2014).

송산리 고분군 내부는 인위적 공조시스템이 중단된 이 후부터 연중 고습한 환경을 유지하고 있으며(Figure $3 \mathrm{~B}$ ), 수분의 영향으로 인한 다양한 유형의 손상이 관찰된다. 5 호분은 부재 표면에서 백화와 흑화현상이 두드러지며, 녹 조류의 흔적이 함께 나타난다(Figure $3 \mathrm{C}$ ). 6호분과 무령왕 릉은 결로에 의한 수분이 벽체에 고정되어 있는 철정을 부 식시켜 벽돌의 변색을 유발하였고(Figure 3D), 미생물의 생장을 돕는 것으로 확인되었다(Figure $3 \mathrm{E}$ ). 현재 이러한 보존환경을 개선하고자 다각적인 연구가 진행 중이다.

한편 6호분 벽화는 개방 이후 급격한 환경변화를 겪으 면서 손상이 가속화되어 바탕층 표면에 백색층만 희미하게 남아 있는 상태이며, 대부분의 백색 안료 또한 결속력을 잃 어 분말화가 진행 중이다. 특히 벽화의 바탕층은 전체적으 로 균열이 많고 결합력이 약해 내부 환경을 건조하게 유지 시킬 경우 균열이 성장하면서 박락이나 탈락으로 이어질 가능성이 높다(Figure $3 \mathrm{~F})$. 따라서 고분의 공간구조와 미기 후 특성에 따른 적합한 보존환경 조성이 필요한 상황이다.

\section{3. 연구방법}

이 연구를 위해 송산리 5.6호분 및 무령왕릉 내부에 자 동 정밀 환경모니터링 시스템을 구축하여 고분의 보존환경 을 분석하고, 미기후 특성을 제어하는 환경 인자를 검토하
여 종합적인 안정성을 고찰하였다. 먼저 송산리 고분군과 관련한 선행연구 및 보수공사 기록을 바탕으로 고분의 내 부조사를 수행하여 정확한 손상 및 보존현황을 파악하였 다. 이후 각 고분의 현실에 온습도 센서와 표면온도 센서, 연도와 전실에는 온습도 센서를 설치하여 공간별로 미기후 를 모니터링 하였다.

현재 고분 내부는 영구폐쇄를 위해 연구목적이라도 출 입이 극히 제한적이다. 따라서 계측센서, 데이터 로거, 모 뎀, 분석용 컴퓨터 등을 이용하여 자동계측시스템을 구축 하였으며, 이를 바탕으로 2013년 12월 8일부터 2015년 8월 8 일까지 20개월 동안 모니터링을 실시하였다. 특히 이 연 구에서는 센서 이상으로 인해 손실된 데이터의 보충과 분 석결과의 신뢰도 향상을 위해 2011에서 2012년까지 선행 되었던 온습도 데이터도 함께 분석하였다.

사계절 변화가 뚜렷하고 여름과 겨울의 기온차가 크게 나타나는 한반도의 기후 특성상 고분 내부라도 외부환경 변화의 영향은 반드시 존재한다. 따라서 자연환경 변화에 따른 미기후 특성을 살펴보기 위해 모니터링을 실시한 동 일기간의 외부 온습도, 일사 및 풍향과 풍속 등의 외기상 데이터를 함께 수집하였다. 외기상 계측장치는 송산리 고 분군 모형전시관의 상부에 설치하였다. 또한 연구자들이 조사를 위해 고분 내부로 출입하였을 때 고분의 미기후 환 경이 일시적인 변화가 발생하였는데, 이 연구에서는 이와 같은 인위적 요인에 의한 변화양상도 분석하였다.
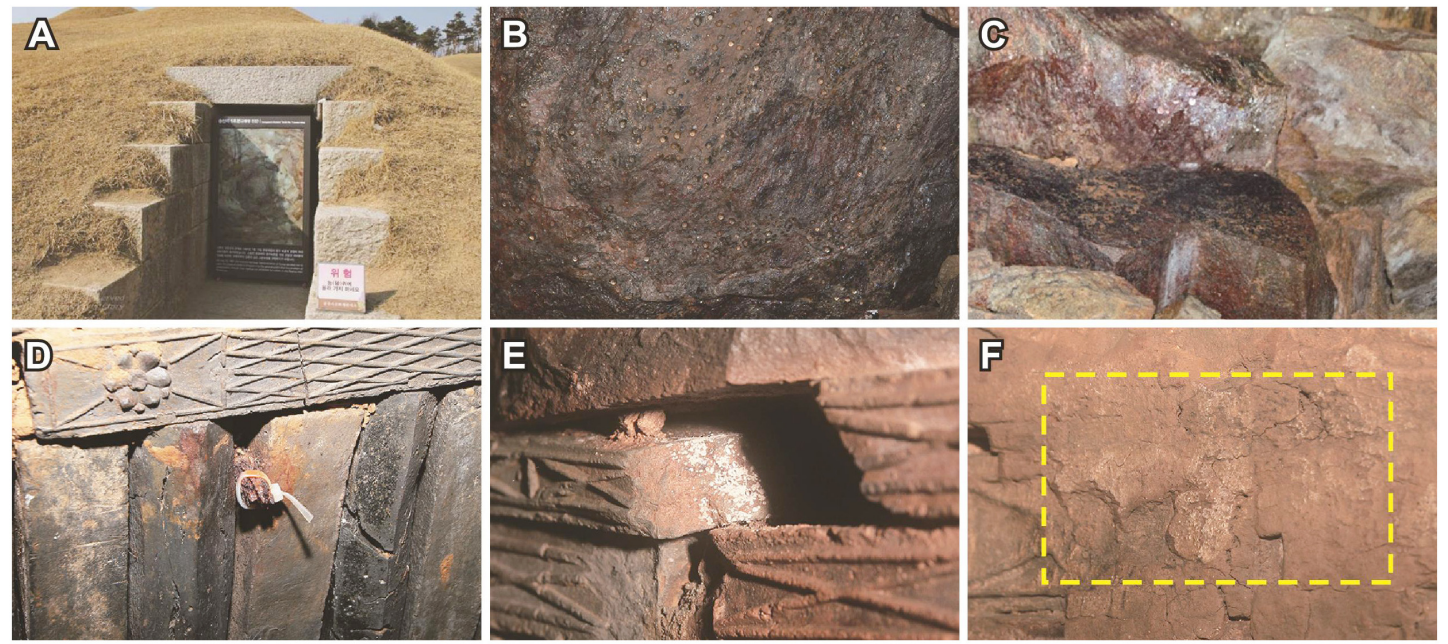

Figure 3. Present status of Royal Tombs at Songsanri. (A) Status of the tombs closed permanently, (B) Condensation on the ceiling in the tomb No. 5, (C) White and black discoloration on the stones in the tomb No. 5, (D) Red discoloration on the bricks by the corrosion of iron nail in Royal Tomb of King Muryeong, (E) White contaminants by microorganisms on the brick in the tomb No. 6, (F) Pulverized white pigments on the bottom layer of the murals in the tomb No. 6. 
미기후 모니터링에 사용한 온습도 센서는 $\pm 0.6 \sim 1.0 \%$ $\mathrm{RH}, \pm 0.05 \sim 0.2^{\circ} \mathrm{C}$ 의 분해능을 가진 핀란드 Vaisala사의 $\mathrm{HMP} 155$ 모델이며, 표면온도 센서는 $\pm 0.2 \sim 0.4^{\circ} \mathrm{C}$ 의 분해 능을 갖고 벽면에 부착이 가능한 미국 Campbell사의 107 모델이다. 또한 외기상의 풍향과 풍속 센서는 풍향 $3^{\circ}$, 풍속 $0.3 \mathrm{~m} / \mathrm{s}$ 의 정확도를 갖는 미국 RM Young의 05103 모델을 이용하였으며, 일사는 공주와 가장 근접한 대전의 기상청 데이터를 활용하였다.

\section{3. 결과 및 해석}

\section{1. 모니터링 과정}

문화유산에 대한 환경모니터링은 목적과 상황에 맞게 기술과 기기 등을 적용하여 문제해결에 필요한 정성적 및 정량적 정보를 획득하고, 이를 바탕으로 취약한 부분의 특 성과 원인을 규명하여 보존환경의 유지관리 방안을 제시하 는 과정을 말한다. 주로 건축 및 석조문화유산의 구조안정 성과 주변 환경을 분석하여 변형을 예측하고 원형을 유지 하기 위한 목적으로 수행하였다(Kim and Lee, 2010; Lee et al., 2010; Martínez-Garrido et al., 2016; Masciotta et al., 2017; Ezcurra and Rivera-Collazo, 2018; Park and Lee, 2018).

이 연구에서는 송산리 고분군에 적합한 보존환경과 장 기적인 관리방안을 마련하기 위해 환경계측시스템을 구축 하여 미기후 특성을 분석하였다. 5 호분과 무령왕릉은 현실 및 연도에, 6 호분은 현실, 연도, 두 개의 전실(이하 연도와 연결되는 곳은 ‘전실 $\mathrm{A}^{\prime}$ 로, 진입로와 연결되는 곳은 ‘전실 B'로 칭함) 및 배수로 공간에 온습도 센서를 설치하였으며, 각 고분의 천장과 바닥 및 네 벽면에는 표면온도센서를 설 치하였다(Figure 4). 특히 벽화가 있으며 가장 복잡한 공간 구조를 갖는 6 호분은 모든 공간에 온습도 센서를 설치하여 집중 모니터링을 수행하였다.

한편 고분 내부는 항시 고습한 환경을 유지하여 모니터 링 기기의 고장이 빈번히 발생하고, 이로 인해 이상 데이터 가 수집되거나 손실되기도 한다. 따라서 모니터링 기간 중 신뢰할 수 있는 안정적인 연간 데이터가 수집된 구간을 선 별하여 분석을 실시하였다. 5호분은 2011년 10월에서 2012년 9월과 2014년 6월에서 2015년 5월의 데이터를, 6 호분과 무령왕릉은 2011년 12월에서 2012년 11월 및 2013 년 12월에서 2014년 11월에 수집한 2년의 데이터를 이용 하였다. 이 연구에서는 편의상 2011 2012년을 1차 분석,

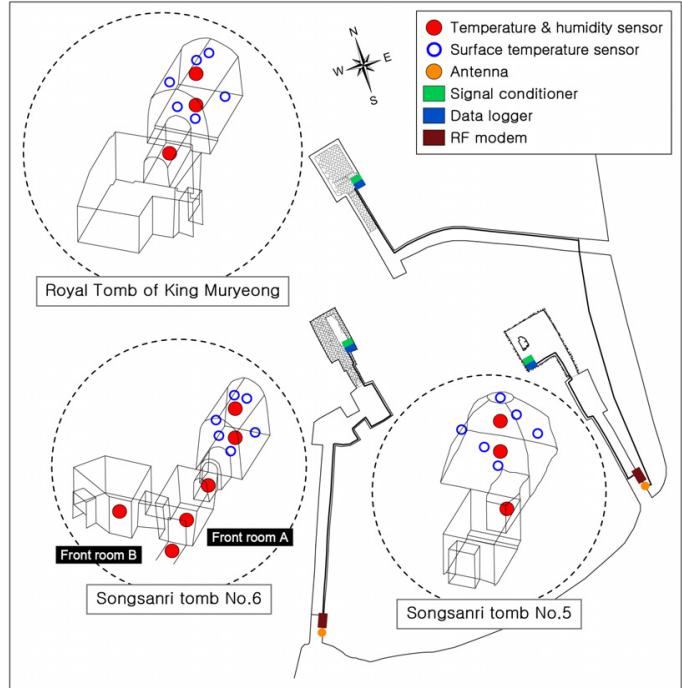

Figure 4. Schematic figures of environmental monitoring systems for Royal Tombs at Songsanri.

2013 2014년을 2차 분석으로 구분하였다.

\section{2. 연간 미기후 특성}

\subsection{1. 송산리 5 호분}

외기는 자연환경의 영향으로 연간 온습도차가 크고, 낮 과 밤의 일교차도 뚜렷하게 나타났으나, 5 호분 현실은 비 교적 안정적인 온습도 분포를 보였다(Figure 5). 외기는 여 름에 최고 $35.5^{\circ} \mathrm{C}$, 겨울에 최저 $-16.9^{\circ} \mathrm{C}$ 로 나타나며 $52.4^{\circ} \mathrm{C}$ 의 연교차를 보였다. 상대습도 또한 최대 $100 \%$, 최소 $11.8 \%$ 를 기록하며 $88.2 \%$ 의 큰 차이가 나타났다. 그러나 고 분 내부는 모니터링 기간 동안 $11.4 \sim 22.1^{\circ} \mathrm{C}$ 의 온도분포를 보였고, 상대습도는 최소 $98.3 \%$ 이상을 유지하며 변화폭이 크지 않은 것으로 확인되었다(Table 1).

한편 고분 내부는 봉분의 축열로 인해 온도그래프의 곡 선패턴이 외기와 두 달 정도의 시간차를 보였으며, 최고온 도와 최저온도는 가을과 봄에 각각 $22.1^{\circ} \mathrm{C}$ 와 $11.4^{\circ} \mathrm{C}$ 로 나 타났다. 상대습도는 최소 $98.3 \%$, 평균 $99.9 \%$ 로서 연중 포 화상태를 유지하고 있다. 이러한 고분 내부의 온도 표준편 차는 3.2 3.3, 습도 표준편차는 0.1로 산출되었으며, 이는 10.5 11.2, 20.2 21.0으로 산출된 외기보다 횔씬 안정적인 수치이다.

고분 내외부의 온도분포 양상을 더 자세히 살펴보기 위 해 연중 일교차가 가장 심한 가을에 강수의 영향이 없었던 두 기간(2012년 09월 21일 09월 30일, 2014년 10월 01 
일 10월 19일)의 데이터를 선별하여 비교분석하였다. 이 결과, 외기의 온도 교차는 각각 $15.9^{\circ} \mathrm{C}$ 와 $23.7^{\circ} \mathrm{C}$ 로, 현실의 온도 교차는 각각 $0.7^{\circ} \mathrm{C}$ 와 $0.4^{\circ} \mathrm{C}$ 로 나타나면서 $15.2^{\circ} \mathrm{C}$ 와 $23.3^{\circ} \mathrm{C}$ 의 차이를 보였다(Table 1$)$. 특히 고분 내부는 온도 교차가 매우 작았으며, 오히려 외기의 온도 교차가 심했던 2014년도가 2012년도보다 더 안정적인 온도분포를 나타냈
다. 이는 2 차 분석시기가 1 차 분석시기보다 온도 교차는 더 컸으나, 연간 온도변화 범위가 작고 표준편차가 낮았기 때 문으로 해석된다.

\subsection{2. 송산리 6 호분}

6호분 현실도 외기상보다 연간 온습도 변화폭이 월등히

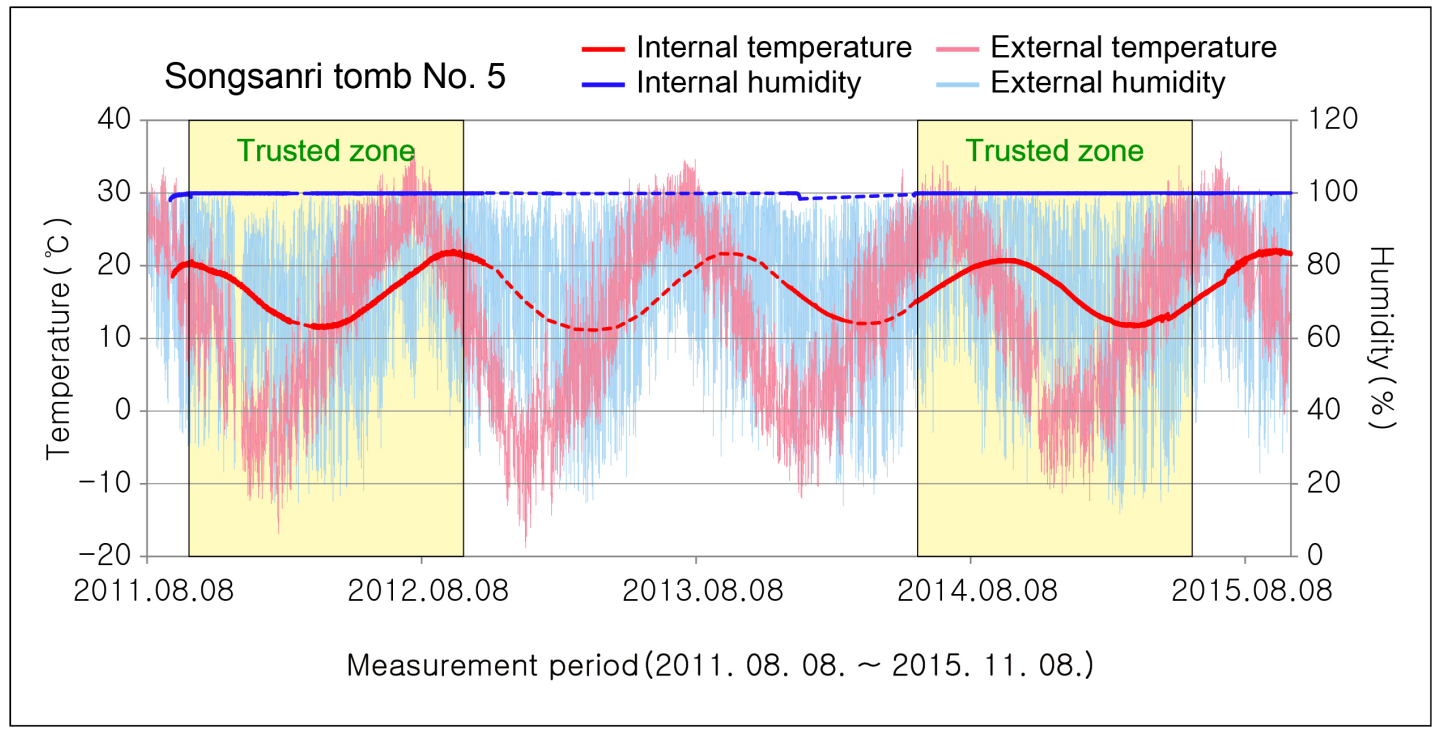

Figure 5. Diagram showing microclimate characteristics of tomb No. 5.

Table 1. Summary on microclimate characteristics of tomb No. 5

\begin{tabular}{|c|c|c|c|c|c|c|}
\hline \multirow{4}{*}{$\begin{array}{l}\text { First } \\
\text { section }\end{array}$} & \multicolumn{4}{|c|}{ Annual } & \multicolumn{2}{|c|}{ Short term } \\
\hline & \multicolumn{4}{|c|}{ 2011. 10.01. 2012.09. 30} & \multirow{2}{*}{\multicolumn{2}{|c|}{$\frac{\text { 2012.09.21. } \sim 2012.09 .30}{\text { Temperature }\left({ }^{\circ} \mathrm{C}\right)}$}} \\
\hline & \multicolumn{2}{|c|}{ Temperature $\left({ }^{\circ} \mathrm{C}\right)$} & \multicolumn{2}{|c|}{ Relative humidity (\%) } & & \\
\hline & Inside & Outside & Inside & Outside & Inside & Outside \\
\hline $\operatorname{Max}$ & 22.1 & 35.5 & 100.0 & 100.0 & 22.0 & 26.2 \\
\hline Min & 11.4 & -16.9 & 98.3 & 14.7 & 21.3 & 10.3 \\
\hline Mean & 16.6 & 12.5 & 99.9 & 73.0 & 21.6 & 17.5 \\
\hline SD & 3.3 & 11.2 & 0.1 & 20.2 & 0.1 & 4.1 \\
\hline \multirow{4}{*}{$\begin{array}{l}\text { Second } \\
\text { section }\end{array}$} & \multicolumn{4}{|c|}{ Annual } & \multicolumn{2}{|c|}{ Short term } \\
\hline & \multicolumn{4}{|c|}{ 2014. 06.01. 2015.05. 31} & \multirow{2}{*}{\multicolumn{2}{|c|}{$\frac{\text { 2014. 10.01. } \sim 2014.10 .19}{\text { Temperature }\left({ }^{\circ} \mathrm{C}\right)}$}} \\
\hline & \multicolumn{2}{|c|}{ Temperature $\left({ }^{\circ} \mathrm{C}\right)$} & \multicolumn{2}{|c|}{ Relative humidity (\%) } & & \\
\hline & Inside & Outside & Outside & Inside & Inside & Outside \\
\hline Max & 20.8 & 33.8 & 100.0 & 100.0 & 20.8 & 26.2 \\
\hline Min & 11.6 & -12.2 & 99.6 & 11.8 & 20.4 & 2.5 \\
\hline Mean & 16.3 & 12.4 & 99.9 & 74.5 & 20.6 & 14.9 \\
\hline SD & 3.2 & 10.5 & 0.1 & 21.0 & 0.1 & 5.2 \\
\hline
\end{tabular}

SD; Standard deviation 
작게 나타났고, 온도 교차도 크지 않아 비교적 안정적인 환 경을 유지하고 있는 것으로 확인되었다(Figure 6). 6호분 현실의 연간 온도변화를 살펴보면, 가을에 최고온도 22. $2^{\circ} \mathrm{C}$, 봄에 최저온도 $11.8^{\circ} \mathrm{C}$ 를 기록하였으며, 평균기온은 $16.8^{\circ} \mathrm{C}$ 로 나타났다. 또한 상대습도는 사람이 출입했을 때 $93.1 \%$ 까지 떨어지기도 하였으나, 평균 $99.9 \%$ 를 유지하며
포화상태를 기록하였다. 6 호분은 1 차 분석에서 5 호분과 매 우 유사한 온도분포를 보였으나, 2차 분석에서는 최고기온 과 평균기온이 각각 $0.8^{\circ} \mathrm{C}$ 와 $0.6^{\circ} \mathrm{C}$ 높게 나타나며 다소 상 이한 양상을 보였다(Table 2). 이는 2차 온도 교차 분석에서 도 동일하게 나타났다.

1 차 온도 교차분석에서 6호분은 5호분과 달리 2012년 9

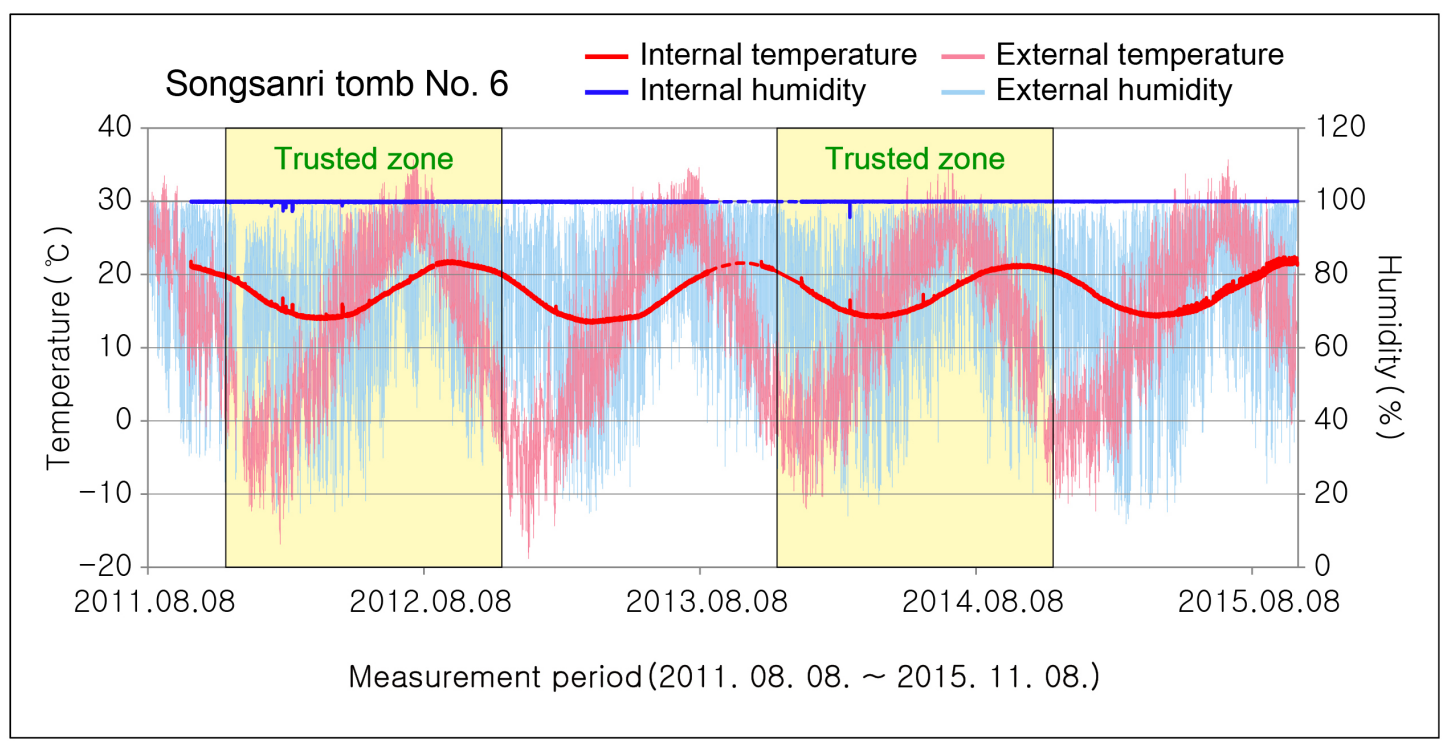

Figure 6. Diagram showing microclimate characteristics of tomb No. 6.

Table 2. Summary on microclimate characteristics of tomb No. 6

\begin{tabular}{|c|c|c|c|c|c|c|}
\hline \multirow{4}{*}{$\begin{array}{l}\text { First } \\
\text { section }\end{array}$} & \multicolumn{4}{|c|}{ Annual } & \multicolumn{2}{|c|}{ Short term } \\
\hline & \multicolumn{4}{|c|}{ 2011. 12.01. 2012. 11. 30} & \multirow{2}{*}{\multicolumn{2}{|c|}{$\frac{\text { 2012.09.21. } \sim 2012.10 .10 .}{\text { Temperature }\left({ }^{\circ} \mathrm{C}\right)}$}} \\
\hline & \multicolumn{2}{|c|}{ Temperature $\left({ }^{\circ} \mathrm{C}\right)$} & \multicolumn{2}{|c|}{ Relative humidity (\%) } & & \\
\hline & Inside & Outside & Inside & Outside & Inside & Outside \\
\hline $\operatorname{Max}$ & 22.2 & 35.5 & 100.0 & 100.0 & 22.0 & 26.2 \\
\hline Min & 11.8 & -16.9 & 95.7 & 14.7 & 21.0 & 8.6 \\
\hline Mean & 16.7 & 12.2 & 99.9 & 73.1 & 21.4 & 16.6 \\
\hline SD & 3.5 & 11.3 & 0.2 & 20.4 & 0.2 & 4.3 \\
\hline \multirow{4}{*}{$\begin{array}{l}\text { Second } \\
\text { section }\end{array}$} & \multicolumn{4}{|c|}{ Annual } & \multicolumn{2}{|c|}{ Short term } \\
\hline & \multicolumn{4}{|c|}{ 2013. 12.08. 2014. 12. 07} & \multirow{2}{*}{\multicolumn{2}{|c|}{$\frac{\text { 2014. 10.01. } \sim 2014.10 .19 .}{\text { Temperature }\left({ }^{\circ} \mathrm{C}\right)}$}} \\
\hline & \multicolumn{2}{|c|}{ Temperature $\left({ }^{\circ} \mathrm{C}\right)$} & \multicolumn{2}{|c|}{ Relative humidity (\%) } & & \\
\hline & Inside & Outside & Outside & Inside & Inside & Outside \\
\hline Max & 21.6 & 33.8 & 100.0 & 100.0 & 21.5 & 26.2 \\
\hline Min & 12.0 & -12.1 & 93.1 & 13.9 & 20.8 & 2.5 \\
\hline Mean & 16.9 & 12.5 & 99.9 & 74.6 & 21.1 & 14.9 \\
\hline SD & 3.3 & 10.3 & 0.1 & 20.3 & 0.1 & 5.2 \\
\hline
\end{tabular}

SD; Standard deviation 
월 21일부터 10 월 10 일까지 20 일 동안 수집한 자료를 바탕 으로 분석을 수행하였다. 이 결과, 외기의 최대 온도 교차 와 표준편차는 5 호분의 분석 시기보다 $1.7^{\circ} \mathrm{C}$ 와 0.2 증가하 였고, 6 호분 현실 또한 최대 온도 교차는 $1.0^{\circ} \mathrm{C}$, 표준편차 는 0.2 로 나타나면서 각각 $0.7^{\circ} \mathrm{C}$ 와 0.1 로 확인된 5 호분보다 불안정한 분포를 보였다. 그러나 6호분 내부는 최대 온도 교차와 표준편차가 $17.6^{\circ} \mathrm{C}$ 와 4.1 로 나타난 외기보다 훨씬 안정적인 양상을 보였다. 2 차 분석결과에서는 매우 유사한 외기 조건에도 5 호분보다 최고, 최저 및 평균기온이 각각 $0.7^{\circ} \mathrm{C}, 0.4^{\circ} \mathrm{C}, 0.5^{\circ} \mathrm{C}$ 높게 나타났다(Table 2). 이는 연간 외 기 온도분포 외에 6 호분에 비교적 큰 영향을 미치는 다른 환경인자가 존재하기 때문으로 판단된다.

6 호분은 5 호분 및 무령왕릉과는 달리 벽화보존에 적합

Table 3. Temperature distribution by construction of space in tomb No. 6

\begin{tabular}{ccccc}
\hline \multirow{2}{*}{$\begin{array}{c}\text { First } \\
\text { section }\end{array}$} & \multicolumn{4}{c}{ 2011. 12. 01. 2012. 11.30. } \\
\cline { 2 - 5 } & $\begin{array}{c}\text { Internal temperature }\left({ }^{\circ} \mathrm{C}\right) \\
\text { chamber }\end{array}$ & Dromos & $\begin{array}{c}\text { Front } \\
\text { room A }\end{array}$ & $\begin{array}{c}\text { Front } \\
\text { room B }\end{array}$ \\
\hline Max & 22.2 & 21.1 & 22.2 & 22.7 \\
Min & 11.8 & 11.8 & 10.5 & 9.4 \\
Mean & 16.7 & 16.2 & 16.2 & 16.3 \\
SD & 3.5 & 3.1 & 3.8 & 4.2 \\
\hline
\end{tabular}

$\mathrm{SD} ;$ Standard deviation
한 환경을 조성해야 한다. 따라서 1 차 분석자료를 이용하 여 연도와 전실에 대한 미기후 특성도 함께 살펴보았다. 이 결과, 출입문과 가까운 전실 $\mathrm{B}$ 는 $9.4 \sim 22.7^{\circ} \mathrm{C}$ 의 온도분포와 4.2 의 표준편차를 보이며 가장 불안정한 양상을 보였고, 전 실 $\mathrm{A}$ 도 비교적 큰 온도변화 $\left(10.5 ~ 22.2^{\circ} \mathrm{C}\right)$ 와 표준편차(3.8) 를 나타냈다.

가장 안정적인 미기후 특성을 보인 공간은 연도로서 온 도분포는 $11.8 \sim 21.1^{\circ} \mathrm{C}$, 표준편차는 3.1 로 나타났다(Table 3). 이는 고분 내부로 유입되는 외부 공기와 밀접한 관계가 있을 것으로 해석된다. 현실보다 연도에서 더 안정적인 온 도분포를 보인 이유는 봉분의 위치에 따른 차별적 축열의 영향도 있으나, 센서의 높이에 따른 온도 차이도 충분히 고 려해야할 것이다.

연도와 전실은 하부에 센서를 설치한 반면, 현실은 공간 이 넓어 상부와 하부로 나누어 센서를 설치하였다. 실제로 고분 내부는 대류의 영향으로 상부와 하부의 온도차가 $1{ }^{\circ} \mathrm{C}$ 이상 나타났으나, 하부 센서의 잦은 고장으로 인해 원활한 자료의 수집에 어려움이 많았다. 배수로 공간도 동일한 사 유로 분석이 불가능하였으며, 향후 현실 하부와 배수로 공 간의 미기후 특성도 함께 분석한다면 더욱 의미 있는 결과 가 도출될 것이다.

\subsection{3. 무령왕릉}

무령왕릉 현실은 외기상 뿐만 아니라 5 호분 및 6 호분 현

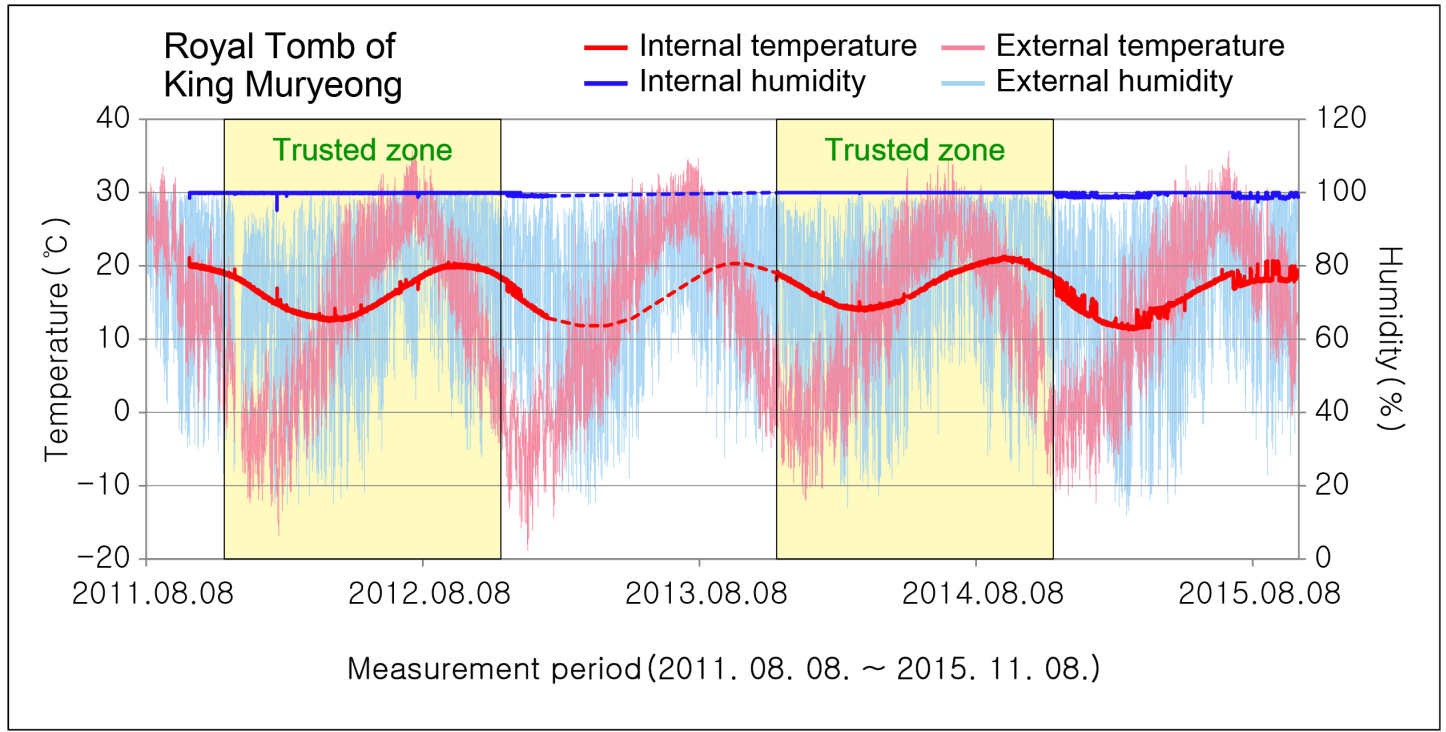

Figure 7. Diagram showing microclimate characteristics for Royal Tomb of King Muryeong. 
Table 4. Summary on microclimate characteristics for Royal Tomb of King Muryeong

\begin{tabular}{|c|c|c|c|c|c|c|}
\hline \multirow{4}{*}{$\begin{array}{l}\text { First } \\
\text { section }\end{array}$} & \multicolumn{4}{|c|}{ Annual } & \multicolumn{2}{|c|}{ Short term } \\
\hline & \multicolumn{4}{|c|}{ 2011. 12.01. 2012. 11. 30} & \multirow{2}{*}{\multicolumn{2}{|c|}{$\begin{array}{c}\text { 2012. 09.21. 2012. 10. } 10 . \\
\text { Temperature }\left({ }^{\circ} \mathrm{C}\right)\end{array}$}} \\
\hline & \multicolumn{2}{|c|}{ Temperature $\left({ }^{\circ} \mathrm{C}\right)$} & \multicolumn{2}{|c|}{ Relative humidity (\%) } & & \\
\hline & Inside & Outside & Inside & Outside & Inside & Outside \\
\hline Max & 20.5 & 35.5 & 100.0 & 100.0 & 20.4 & 26.2 \\
\hline Min & 12.4 & -16.9 & 94.2 & 14.7 & 19.7 & 8.6 \\
\hline Mean & 16.3 & 12.2 & 99.9 & 73.1 & 19.9 & 16.6 \\
\hline SD & 2.6 & 11.3 & 0.1 & 20.4 & 0.1 & 4.3 \\
\hline \multirow{4}{*}{$\begin{array}{l}\text { Second } \\
\text { section }\end{array}$} & \multicolumn{4}{|c|}{ Annual } & \multicolumn{2}{|c|}{ Short term } \\
\hline & \multicolumn{4}{|c|}{ 2013. 12. 08. 2014. 12. 07.} & \multirow{2}{*}{\multicolumn{2}{|c|}{$\begin{array}{c}\text { 2014. 10. 01. 2014. 10. } 19 . \\
\text { Temperature }\left({ }^{\circ} \mathrm{C}\right)\end{array}$}} \\
\hline & \multicolumn{2}{|c|}{ Temperature $\left({ }^{\circ} \mathrm{C}\right)$} & \multicolumn{2}{|c|}{ Relative humidity (\%) } & & \\
\hline & Inside & Outside & Outside & Inside & Inside & Outside \\
\hline Max & 21.3 & 33.8 & 100.0 & 100.0 & 21.3 & 26.2 \\
\hline Min & 13.8 & -12.1 & 97.6 & 13.9 & 20.6 & 2.5 \\
\hline Mean & 17.0 & 12.5 & 99.9 & 74.6 & 20.9 & 14.9 \\
\hline SD & 2.4 & 10.3 & 0.1 & 20.3 & 0.1 & 5.2 \\
\hline
\end{tabular}

SD; Standard deviation

실보다도 더 안정적인 미기후 특성을 보였다(Figure 7). 무 령왕릉은 가을에 최고온도 $21.3^{\circ} \mathrm{C}$, 봄에 최저온도 $12.4^{\circ} \mathrm{C}$ 를 나타냈으며, 외기 온도와의 차이는 각각 $14.2^{\circ} \mathrm{C}$ 와 29 . $3{ }^{\circ} \mathrm{C}$ 로 확인되었다. 상대습도는 $94.2 \sim 100 \%$ 사이에서 변화 하였고, 평균 $99.9 \%$ 를 유지하였다(Table 4). 특히 무령왕릉 은 5 호분 및 6 호분보다 변화폭이 $1.5^{\circ} \mathrm{C}$ 이상 작았다. 또한 표준편차는 2.4 2.6으로서 5호분(3.2 3.3)과 6 호분(3.3 3.5) 에 비해 0.6 이상 낮게 나타났다. 이와 같이 무령왕릉의 현 실은 가장 안정적인 온도분포를 보였다.

온도의 교차분석 결과, 외기는 1 차에 $17.6^{\circ} \mathrm{C}, 2$ 차에 23 . $7^{\circ} \mathrm{C}$ 로 나타났고, 표준편차도 각각 4.3 과 5.2 로 산출되었다. 그러나 무령왕릉 현실은 모두 $0.7^{\circ} \mathrm{C}$ 의 교차와 0.1 의 표준 편차가 나타나며 매우 안정적인 양상을 보였다. 2차 분석 결과가 1 차 분석 때보다 온도 교차가 6.1 높았음에도 유사 한 결과가 나타난 이유는 2 차 분석 때의 연간 온도분포가 1 차 분석 때보다 더욱 안정적으로 나타났기 때문이다.

온도 교차분석 결과로 볼 때, 6 호분과 무령왕릉은 동일 한 조건으로 분석하였으나 상반된 특징이 나타났다. 2 차 분석에서 6 호분은 전반적으로 온도분포가 감소한 반면, 무 령왕릉은 증가하였다. 이는 고분의 미기후에 영향을 미치 는 여러 환경인자가 상호 복합적으로 작용하기 때문이며, 정확한 보존환경의 진단을 위해서는 다양한 조건에 대한 분석이 필요할 것으로 판단된다.

\section{3. 보존환경 영향인자}

\subsection{1. 외기 유입}

송산리 고분군은 계절마다 조금씩 다른 미시대류가 형 성되며, 이로 인해 고분 내부로 유입되는 외기의 양도 차이 가 있다. 이 연구에서는 외기의 영향을 살펴보기 위해 먼저 6 호분의 1 차 분석결과를 검토하였다. 이 결과, 겨울은 현실 $\left(12.3 \sim 18.4^{\circ} \mathrm{C}\right)$ 이 외기 $\left(-16.9 \sim 12.6^{\circ} \mathrm{C}\right)$ 보다 높은 온도분포를, 여름은 현실 $\left(14.9 \sim 21.8^{\circ} \mathrm{C}\right)$ 이 외기 $\left(13.0 \sim 35.5^{\circ} \mathrm{C}\right)$ 보다 낮은 온도를 보였다. 그러나 봄과 가을에는 내부와 외기의 온도 가 서로 교차하면서 서서히 전환되는 경향을 나타냈다 (Table 5, Figure 6).

따라서 겨울에는 고분 내부에서 외부로, 여름에는 외부 에서 고분 내부로 공기의 이동이 발생하게 되며, 이는 현실 의 온도와 표준편차 분석 결과를 통해서도 확인할 수 있다. 현실은 겨울과 여름에 온도 교차와 표준편차가 각각 6.1 과 1.5 및 6.9 와 1.8 로 크게 나타나면서 봄(온도 교차; 3.5 , 표 준편차; 0.9)과 가을(온도 교차; 4.3 , 표준편차; 1.1)보다 다 소 불안정한 온도분포를 보였다(Table 5). 이를 종합하면, 고분 내부와 외기 사이의 대류운동은 비교적 겨울과 여름 에 활발하게 이루어졌음을 알 수 있다.

또한 외기의 영향을 더욱 면밀히 살펴보기 위해 겨울과 여름에 수집한 데이터만을 이용하여 6 호분의 공간별 온도 
Table 5. Temperature distribution by seasonal change in tomb No. 6

\begin{tabular}{cccccccccc}
\hline & \multicolumn{7}{c}{ 2011. 12.01. 2012. 11. 30. } \\
\cline { 2 - 9 } Nomb 6 & \multicolumn{7}{c}{ Internal temperature $\left({ }^{\circ} \mathrm{C}\right)$} \\
\cline { 2 - 10 } & Winter & Spring & Summer & Autumn & Winter & Spring & Summer & Autumn \\
\hline Max & 18.4 & 15.3 & 21.8 & 22.2 & 12.6 & 29.8 & 35.5 & 29.3 \\
Min & 12.3 & 11.8 & 14.9 & 17.9 & -16.9 & -6.5 & 13.0 & -4.4 \\
Mean & 14.7 & 12.7 & 18.5 & 20.7 & -2.2 & 11.8 & 24.8 & 12.5 \\
SD & 1.5 & 0.9 & 1.8 & 1.1 & 5.1 & 7.8 & 3.9 & 7.4 \\
\hline
\end{tabular}

SD; Standard deviation

Table 6. Temperature distribution at tomb No. 6 of summer and winter in 2012

\begin{tabular}{ccccccccc}
\hline Season & \multicolumn{4}{c}{ Winter } & \multicolumn{3}{c}{ Summer } \\
\hline Heat shift & \multicolumn{3}{c}{ Inside $\rightarrow$ Outside } & \multicolumn{3}{c}{ Inside $\leftarrow$ Outside } \\
\hline Space & $\begin{array}{c}\text { Burial } \\
\text { chamber }\end{array}$ & Dromos & $\begin{array}{c}\text { Front } \\
\text { room A }\end{array}$ & $\begin{array}{c}\text { Front } \\
\text { room B }\end{array}$ & $\begin{array}{c}\text { Burial } \\
\text { chamber }\end{array}$ & Dromos & $\begin{array}{c}\text { Front } \\
\text { room A }\end{array}$ & $\begin{array}{c}\text { Front } \\
\text { room B }\end{array}$ \\
\hline Max & 18.4 & 17.7 & 17.2 & 16.8 & 21.8 & 20.9 & 22.2 & 22.7 \\
Min & 12.3 & 11.9 & 10.7 & 9.9 & 14.9 & 14.6 & 15.2 & 15.9 \\
Mean & 14.7 & 14.2 & 13.3 & 12.4 & 18.5 & 17.7 & 18.9 & 19.8 \\
SD & 1.5 & 1.5 & 1.8 & 1.9 & 1.8 & 1.8 & 2.0 & 1.8 \\
\hline
\end{tabular}

SD; Standard deviation

분포를 분석하였다. 겨울에는 공간에 따른 온도특성이 뚜 렷하게 구분되며, 전실 $\mathrm{B}$ 는 $9.9 \sim 16.8^{\circ} \mathrm{C}$ 의 낮은 온도분포를 보였고, 평균기온도 $12.4^{\circ} \mathrm{C}$ 로 가장 낮게 나타났다. 반면 현 실의 온도는 $12.3 \sim 18.4$ (평균 14.7$)^{\circ} \mathrm{C}$ 로 가장 높았다. 또한 온도의 표준편차는 $\mathrm{B}>$ 전실 $>\mathrm{A}>$ 연도=현실 순으로 높게 나 타났는데, 이는 출입문과 가까이 위치한 전실이 외기의 영 향을 많이 받기 때문으로 보인다(Table 6).

여름은 겨울과는 다소 달라 외부에서 고분 내부로 더운 공기가 이동하기 때문에 전실 $\mathrm{B}>$ 전실 $\mathrm{A}>$ 연도순으로 높은 온도분포를 보였다. 그러나 현실은 연도보다 온도변화의 범위가 더 크고, 평균기온도 높게 나타나며 다소 불안정하 였다. 또한 여름에는 겨울과 달리 온도의 표준편차가 공간 별로 뚜렷한 특징을 보이지 않고, 모두 유사하게 나타났다. 다만 전실 $\mathrm{A}$ 의 표준편차가 다른 공간들보다 0.2 높게 나타 났는데, 이는 전실 $\mathrm{A}$ 가 진입로와 전실 $\mathrm{B}$ 를 따라 유입되는 외부 공기 및 배수로를 통해 유입되는 외부 공기의 영향을 받기 때문으로 판단된다(Table 6).

계절변화에 따른 외기의 영향은 5 호분과 무령왕릉에서 도 동일하게 나타났다. 5호분과 무령왕릉 모두 여름에는 현실(5호분; $15.6 \sim 20.5^{\circ} \mathrm{C}$, 무령왕릉; $13.7 \sim 19.6^{\circ} \mathrm{C}$ )이 외기
(2014년; $15.1 ~ 33.8^{\circ} \mathrm{C}, 2011$ 년; $13.0 ~ 35.5^{\circ} \mathrm{C}$ )보다 낮은 온 도분포를 보였고, 겨울에는 현실 $\left(5\right.$ 호분; $11.7 \sim 17.8^{\circ} \mathrm{C}$, 무령 왕릉; $13.3 \sim 18.5^{\circ} \mathrm{C}$ )이 외기(2014년; $-12.4 \sim 11.7^{\circ} \mathrm{C}, 2011$ 년; $\left.-16.9 \sim 12.6^{\circ} \mathrm{C}\right)$ 보다 높게 나타났다. 표준편차는 내외부의 온도차가 커 대류운동이 활발히 이루어지는 여름(5호분; 1.6 , 무령왕릉; 1.6 )과 겨울(5호분; 1.8 , 무령왕릉; 1.5 )이 봄 (5호분; 0.9 , 무령왕릉; 0.4 )이나 가을(5호분; 0.9 , 무령왕릉; $0.5)$ 보다 높은 것으로 기록되었다(Table 7,8$)$.

\subsection{2. 일사}

일사는 대기 또는 지표의 어느 한 점에 도달한 태양복사 를 말하며, 일사량은 하루 중 태양고도가 가장 높은 남중시, 연중에는 하지경에 최대가 된다. 이 연구에서는 일사에 따 른 고분 내부의 미기후 특성을 검토하기 위해 하지가 포함 되어 있는 6월부터 축열의 영향으로 인한 내외부의 시간차 를 고려하여 8 월까지 3 개월 동안의 온도분포와 표준편차 를 분석하였다. 또한 일사의 영향을 비교분석하기 위해 연 간 일사가 가장 약하게 나타난 겨울철(12월 2월)의 온도 자료도 함께 검토하였다. Table 9의 일사량은 하루에 발생 한 일사의 합을 의미한다. 
Table 7. Temperature distribution by seasonal change in tomb No. 5

\begin{tabular}{ccccccccc}
\hline & \multicolumn{7}{c}{ 2014.06. 01. 2015. 05. 31. } \\
\cline { 2 - 9 } Nomb & \multicolumn{3}{c}{ Internal temperature $\left({ }^{\circ} \mathrm{C}\right)$} \\
\cline { 2 - 10 } & Summer & Autumn & Winter & Spring & Summer & Autumn & Winter & Spring \\
\hline Max & 20.5 & 20.8 & 17.8 & 15.1 & 33.8 & 30.4 & 11.7 & 31.1 \\
Min & 15.6 & 17.5 & 11.7 & 11.6 & 15.1 & -3.1 & -12.4 & -7.5 \\
Mean & 18.8 & 19.9 & 14.2 & 12.8 & 23.5 & 13.8 & -0.8 & 12.0 \\
SD & 1.6 & 0.9 & 1.8 & 0.9 & 3.4 & 7.0 & 4.4 & 7.7 \\
\hline
\end{tabular}

SD; Standard deviation

Table 8. Temperature distribution by seasonal change in Royal Tomb of King Muryeong

\begin{tabular}{ccccccccc}
\hline \multirow{2}{*}{$\begin{array}{c}\text { Royal } \\
\text { Tomb of King } \\
\text { Muryeong }\end{array}$} & \multicolumn{9}{c}{ 2011. 12. 01. 2012. 11.30. } \\
\cline { 2 - 9 } & Winter & Spring & Summer & Autumn & Winter & Spring & Summer & Autumn \\
\hline Max & 18.5 & 14.7 & 19.6 & 20.5 & 12.6 & 29.8 & 35.5 & 29.3 \\
Min & 13.3 & 12.4 & 13.7 & 18.1 & -16.9 & -6.5 & 13.0 & -4.4 \\
Mean & 15.8 & 13.1 & 16.8 & 19.6 & -2.2 & 11.8 & 24.8 & 12.5 \\
SD & 1.5 & 0.4 & 1.6 & 0.5 & 5.1 & 7.8 & 3.9 & 7.4 \\
\hline
\end{tabular}

SD; Standard deviation

Table 9. Temperature distribution by solar radiation quantity of June in 2012 and 2014

\begin{tabular}{|c|c|c|c|c|c|c|c|c|}
\hline \multirow{3}{*}{$\begin{array}{c}\text { First } \\
\text { section }\end{array}$} & \multicolumn{4}{|c|}{ 2012.06.01. 2012.08. 31.} & \multicolumn{4}{|c|}{ 2011. 12.01. 2012.02. 29.} \\
\hline & \multicolumn{3}{|c|}{ Internal temperature $\left({ }^{\circ} \mathrm{C}\right)$} & \multirow{2}{*}{$\begin{array}{c}\text { Solar } \\
\text { radiation } \\
\left(\text { day, } \mathrm{MJ} / \mathrm{m}^{2}\right)\end{array}$} & \multicolumn{3}{|c|}{ Internal temperature $\left({ }^{\circ} \mathrm{C}\right)$} & \multirow{2}{*}{$\begin{array}{c}\text { Solar } \\
\text { radiation } \\
\left(\text { day, } \mathrm{MJ} / \mathrm{m}^{2}\right)\end{array}$} \\
\hline & $\begin{array}{l}\text { Tomb } \\
\text { No. } 5\end{array}$ & $\begin{array}{l}\text { Tomb } \\
\text { No. } 6\end{array}$ & $\begin{array}{c}\text { Royal Tomb } \\
\text { King Muryeong }\end{array}$ & & $\begin{array}{l}\text { Tomb } \\
\text { No. } 5\end{array}$ & $\begin{array}{l}\text { Tomb } \\
\text { No. } 6\end{array}$ & $\begin{array}{c}\text { Royal Tomb } \\
\text { King Muryeong }\end{array}$ & \\
\hline Max & 21.6 & 21.8 & 19.6 & 27.9 & 18.2 & 18.4 & 18.5 & 18.6 \\
\hline Min & 14.5 & 14.9 & 13.7 & 1.3 & 12.1 & 12.3 & 13.3 & 1.9 \\
\hline Mean & 18.2 & 18.5 & 16.8 & 17.1 & 14.9 & 14.7 & 15.8 & 9.9 \\
\hline SD & 2.0 & 1.8 & 1.6 & 7.7 & 1.7 & 1.5 & 1.5 & 3.8 \\
\hline \multirow{3}{*}{$\begin{array}{l}\text { Second } \\
\text { section }\end{array}$} & \multicolumn{4}{|c|}{ 2014.06.01. 2014.08. 31.} & \multicolumn{4}{|c|}{ 2013. 12. 08. 2014. 02. 28.} \\
\hline & \multicolumn{3}{|c|}{ Internal temperature $\left({ }^{\circ} \mathrm{C}\right)$} & & \multicolumn{3}{|c|}{ Internal temperature $\left({ }^{\circ} \mathrm{C}\right)$} & Solar \\
\hline & $\begin{array}{l}\text { Tomb } \\
\text { No. } 5 \\
\end{array}$ & $\begin{array}{l}\text { Tomb } \\
\text { No. } 6 \\
\end{array}$ & $\begin{array}{c}\text { Royal Tomb } \\
\text { King Muryeong }\end{array}$ & $\begin{array}{c}\text { radiation } \\
\left(\text { day, } \mathrm{MJ} / \mathrm{m}^{2}\right)\end{array}$ & $\begin{array}{l}\text { Tomb } \\
\text { No. } 5 \\
\end{array}$ & $\begin{array}{l}\text { Tomb } \\
\text { No. } 6 \\
\end{array}$ & $\begin{array}{c}\text { Royal Tomb } \\
\text { King Muryeong }\end{array}$ & $\begin{array}{c}\text { radiation } \\
\left(\text { day, } \mathrm{MJ} / \mathrm{m}^{2}\right)\end{array}$ \\
\hline Max & 20.5 & 21.5 & 20.4 & 29.8 & - & 17.9 & 19.0 & 17.9 \\
\hline Min & 15.6 & 15.7 & 15.1 & 3.2 & - & 12.1 & 14.3 & 0.7 \\
\hline Mean & 18.8 & 19.0 & 18.1 & 17.3 & - & 14.4 & 16.6 & 9.8 \\
\hline SD & 1.6 & 1.6 & 1.3 & 7.2 & - & 1.6 & 1.3 & 3.7 \\
\hline
\end{tabular}

SD; Standard deviation

1 차 분석에서는 여름이 겨울보다 최대 일사량이 9.3(평 균 7.2) $\mathrm{MJ} / \mathrm{m}^{2}$ 높게 나타났고, 각 고분의 현실에서 산출된 온도의 표준편차도 5 호분이 2.0 과 $1.7,6$ 호분이 1.8 과 1.5 ,
무령왕릉이 1.6 과 1.5 로서 여름이 겨울보다 높은 것으로 기 록되었다. 2 차 분석에서는 5 호분의 센서 이상으로 6 호분과 무령왕릉에 대한 분석만 가능하였다. 2 차 분석은 여름과 
겨울의 최대 및 평균 일사량 차이가 각각 $11.9 \mathrm{MJ} / \mathrm{m}^{2}$ 와 7.5 $\mathrm{MJ} / \mathrm{m}^{2}$ 로서 1차 분석 때보다 일사의 영향이 컸으나, 6 호분 과 무령왕릉 현실의 온도분포에 대한 표준편차는 동일하게 나타났다(Table 9). 이는 분석시점이 외기의 유입이 활발하 게 이루어지는 때로서 여러 환경인자가 복합적으로 작용하 여 나타난 결과로 해석된다.

이를 고분별로 살펴보면, 무령왕릉 현실은 5 호분 및 6 호 분의 현실에 비해 온도변화 범위가 작고, 표준편차도 더 낮 게 나타났다. 이와 같이 무령왕릉이 다른 고분에 비해 안정 적인 온도분포를 보인 이유는 봉분의 두께와 관련이 있는 것으로 설명할 수 있다. 각 현실의 천장에서 수직으로 만나 는 봉토층과의 연직거리는 5 호분이 $2.3 \mathrm{~m}, 6$ 호분이 $3.4 \mathrm{~m}$, 무령왕릉이 $3.8 \mathrm{~m}$ 로 무령왕릉의 봉분이 가장 두껍다. 봉분 이 두꺼울수록 일사에 의해 가열되고 축적된 열은 냉각속 도가 느리게 나타나기 때문에 무령왕릉의 온도변화가 비교 적 적게 나타난 것으로 해석된다.

한편 6호분은 5호분보다 봉분의 두께가 $1.1 \mathrm{~m}$ 나 두꺼움 에도 불구하고 2 차 분석에서 더 불안정한 온도분포가 나타 났다. 이 이유 또한 외기의 유입과 밀접한 관계가 있으며, 6 호분이 외기의 유입통로가 5 호분보다 많기 때문으로 보인다. 이 결과를 종합하면, 여름철에는 고분의 미기후를 변화시 키는 여러 환경인자가 동시에 작용하며, 일사는 봉분의 두 께에 따라 차별적인 영향을 미치는 것으로 해석할 수 있다.

\subsection{3. 풍향 및 풍속}

바람은 기압의 변화 또는 사람이나 기계에 의해 일어나 는 공기의 움직임을 의미하며, 주로 방향과 속도를 계측함 으로서 그 영향을 알 수 있다. 이 연구에서는 고분의 미기 후 특성과 바람의 연관성을 살펴보기 위해 6호분과 무령왕 릉을 대상으로 평상시와 바람이 강하게 불었던 날을 선정 하여 온도분포와 표준편차를 비교분석하였다(Figure 8). 6 호분과 무령왕릉은 출입구가 각각 남쪽과 동쪽에 위치하여 남풍과 동풍이 우세하였던 특정 기간의 기록을 선별하였으 며, 바람을 제외한 기상조건이 유사하도록 강우가 발생하 지 않은 동년 동월의 자료를 이용하였다.

송산리 고분군에서 수집한 풍향과 풍속은 연간 서풍의 빈도가 높았으며, 북풍과 남풍이 상대적으로 낮은 빈도를 보였다. 풍속은 평균 $0.9 \mathrm{~m} / \mathrm{s}$ 로서 대부분 $2.0 \mathrm{~m} / \mathrm{s}$ 이내로 나타 났으나, 바람이 강하게 불었던 날은 $5.0 \mathrm{~m} / \mathrm{s}$ 이상을 기록하 였다(Figure 8). 이 중 6호분은 최대 풍속이 6.7(평균 1.4) $\mathrm{m} / \mathrm{s}$ 로 나타난 2012년 2월 17 18일과 최대 1.9(평균 0.5) m/s 의 풍속을 보인 2012년 2월 21 22일의 자료를, 무령왕릉은 최대 풍속이 각각 7.5 (평균 2.5 ) $\mathrm{m} / \mathrm{s}$ 와 2.1(평균 0.5$) \mathrm{m} / \mathrm{s}$ 로 나 타난 2012년 4월 8 9일과 2012년 4월 13 14일의 자료를 이용하여 비교분석하였다(Table 10,11$)$.

6 호분과 무령왕릉 모두 바람이 강하게 불었던 기간의 온도분포가 더 불안정하게 나타났으며, 특히 6호분은 공간 구조에 따른 특성이 반영된 결과를 보였다. 6 호분은 바람

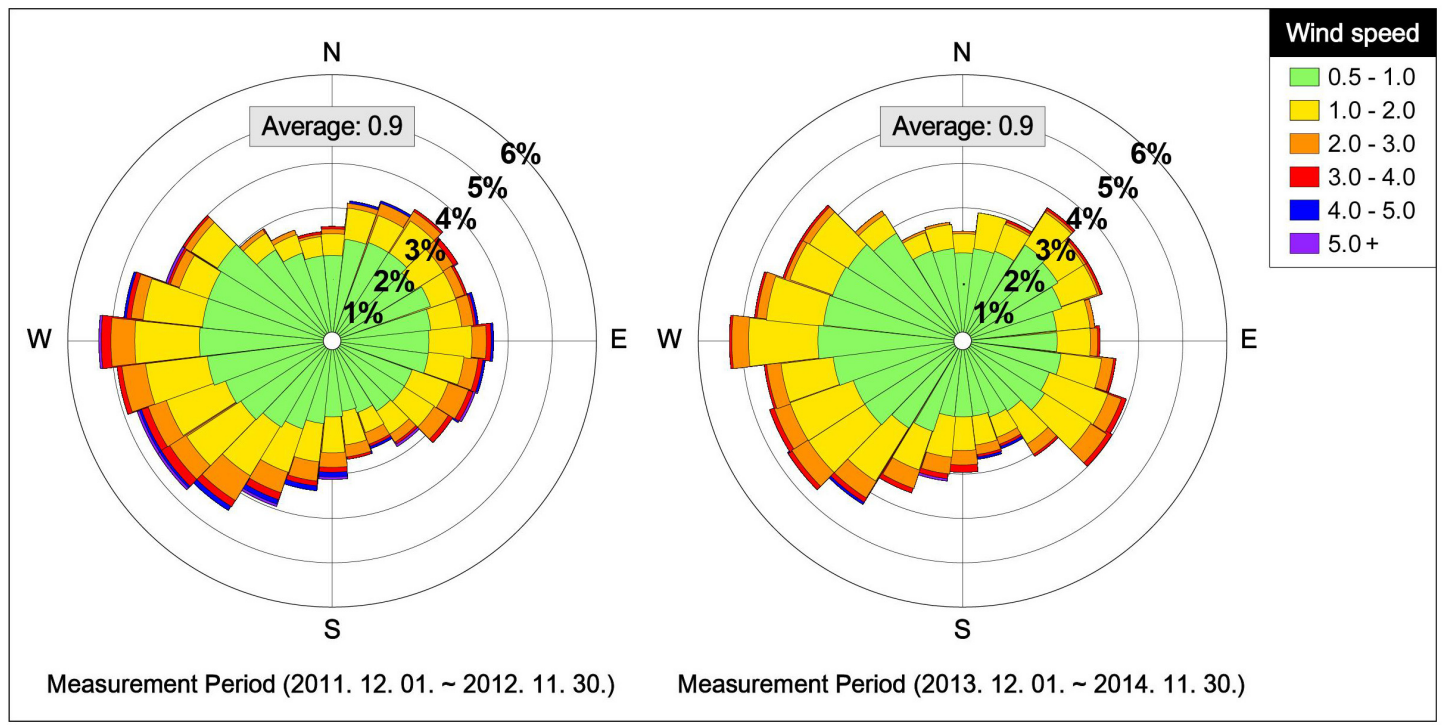

Figure 8. Rose diagrams showing wind direction and speed collected in Royal Tombs at Songsanri. 
Table 10. Temperature distribution by wind in tomb No. 6

\begin{tabular}{ccccccccc}
\hline Date & \multicolumn{3}{c}{ 2012. 02. 17. 2012.02. 18. } & \multicolumn{3}{c}{ 2012. 02. 21. 2012. 02.22. } \\
\hline Wind speed & \multicolumn{3}{c}{ Max; 6.7 m/s, Average; 1.4 m/s } & \multicolumn{3}{c}{ Max; 1.9 m/s, Average; 0.5 m/s } \\
\hline Space & $\begin{array}{c}\text { Front } \\
\text { room B }\end{array}$ & $\begin{array}{c}\text { Front } \\
\text { room A }\end{array}$ & Dromos & $\begin{array}{c}\text { Burial } \\
\text { chamber }\end{array}$ & $\begin{array}{c}\text { Front } \\
\text { room B }\end{array}$ & $\begin{array}{c}\text { Front } \\
\text { room A }\end{array}$ & Dromos & Burial chamber \\
\hline Max & 11.0 & 11.3 & 12.8 & 12.9 & 10.9 & 11.3 & 12.7 & 12.6 \\
Min & 10.5 & 10.9 & 12.4 & 12.5 & 10.4 & 10.8 & 12.2 & 12.3 \\
Mean & 10.7 & 11.0 & 12.6 & 12.6 & 10.6 & 11.0 & 12.4 & 12.4 \\
SD & 0.130 & 0.116 & 0.106 & 0.111 & 0.113 & 0.105 & 0.098 & 0.104 \\
\hline
\end{tabular}

SD; Standard deviation

Table 11. Temperature distribution by wind in Royal Tomb of King Muryeong

\begin{tabular}{ccc}
\hline Date & $2012.04 .08 . \sim 2012.04 .09$. & $2012.04 .13 . \sim 2012.04 .14$. \\
\hline Speed & Max; $7.5 \mathrm{~m} / \mathrm{s}$, Mean; $2.0 \mathrm{~m} / \mathrm{s}$ & Max; $2.1 \mathrm{~m} / \mathrm{s}$, Mean; $0.5 \mathrm{~m} / \mathrm{s}$ \\
\hline Space & Burical chamber & Burical chamber \\
\hline Max & 13.0 & 12.9 \\
Min & 12.5 & 12.5 \\
Mean & 12.7 & 12.7 \\
SD & 0.107 & 0.097 \\
\hline
\end{tabular}

SD; Standard deviation

의 영향으로 내부 온도가 상승하지는 않았으나, 전실 $\mathrm{B}$ 는 0.017 , 전실 $\mathrm{A}$ 는 0.011, 연도는 0.008 , 현실은 0.007 의 표준 편차가 증가하였다. 증가량만 보면, 출입문부터 가까이 위 치한 전실 $\mathrm{B}>$ 전실 $\mathrm{A}>$ 연도>현실 순으로 높게 나타났다 (Table 10).

무령왕릉은 현실만 분석하였다. 이 결과, 온도분포는 유 사하게 나타났으며 표준편차만 0.010 증가한 것으로 확인 되었다(Table 11). 이는 바람의 영향으로 인해 고분 내부로 유입되는 외기의 양이 증가하였기 때문으로 보인다. 5 호분 은 자료의 노이즈가 많아 분석을 수행하지는 못하였으나, 6 호분 및 무령왕릉과 동일한 경향을 보일 것으로 판단된다.

\subsection{4. 인위적 변화}

송산리 고분군의 현실은 현재 밀폐된 상태로 연간 $11.4 \sim 22.2^{\circ} \mathrm{C}$ 이내에서 비교적 안정적인 온도분포를 유지 하나, 연구목적으로 사람이 출입하면 내부 기온은 일시적 으로 상승하는 경향을 보인다. 따라서 고분 내부로 출입한 인원, 시간 등을 기록한 출입일지와 환경계측 자료를 바탕 으로 사람의 출입이 고분의 미기후에 미치는 영향을 검토 하였다. 6 호분과 무령왕릉의 현실을 대상으로, 2014년 2월
6 일, 3 월 27 일, 5 월 12 일 및 6 월 26 일의 온도분포를 분석하 였다(Table 12, Figure 9).

6 호분의 경우 출입 인원이 4 명, 재실시간이 90 분이었을 때 $2.0^{\circ} \mathrm{C}, 2$ 명의 인원이 40 분 동안 머물렀을 때는 $1.1^{\circ} \mathrm{C}$ 의 온도가 증가하였다. 또한 3 명이 각각 20 분과 90 분씩 머물 렀을 때는 $1.1^{\circ} \mathrm{C}$ 와 $1.9^{\circ} \mathrm{C}$ 의 기온이 상승하였다(Table 12) 이와 같이 6 호분 현실의 기온은 출입 인원이 같을 때 재실 시간에 비례하여 상승하였고, 재실시간이 같을 경우에는 출입 인원에 비례하여 높아지는 양상을 나타냈다.

무령왕릉은 3 월 27 일에 약 3 시간의 시간차를 두고 두 차 례 출입하였으며, 이로 인해 두 구간에서 기온이 상승하는 특징을 보였다. 3 명이 50 분 동안 머무른 1 차 출입에서는 $1.3^{\circ} \mathrm{C}, 2$ 명이 60 분 동안 머무른 2 차 출입에서는 $0.9^{\circ} \mathrm{C}$ 의 온 도가 증가하였다. 무령왕릉은 2월 6일 및 5월 12 일과 같이 4 명이 30 분 동안 머물렀을 때와 3 명이 20 분 동안 머물렀을 때의 온도 증가량이 $1.0^{\circ} \mathrm{C}$ 로 동일하게 나타나기도 하였다 (Table 12). 이는 외부에서 고분 내부로 공기의 이동이 발생 하는 5 월 12 일이 이와 반대되는 대류를 형성하는 2 월 6 일 보다 출입문 개방으로 인해 유입되는 외기의 양이 더 많아 미기후 환경이 크게 교란되었기 때문으로 판단된다. 
특히 인위적 환경변화가 발생하였을 때 현실의 대기온 도 상승량 $\left(1.89^{\circ} \mathrm{C}\right)$ 은 천장, 바닥 및 벽면의 표면온도 상승
량(천장; $0.72^{\circ} \mathrm{C}$, 바닥; $0.58^{\circ} \mathrm{C}$, 동벽; $0.69^{\circ} \mathrm{C}$, 서벽; $0.74^{\circ} \mathrm{C}$, 남벽; $0.70^{\circ} \mathrm{C}$, 북벽; $0.66^{\circ} \mathrm{C}$ )보다 2 배 이상 높게 나타났다

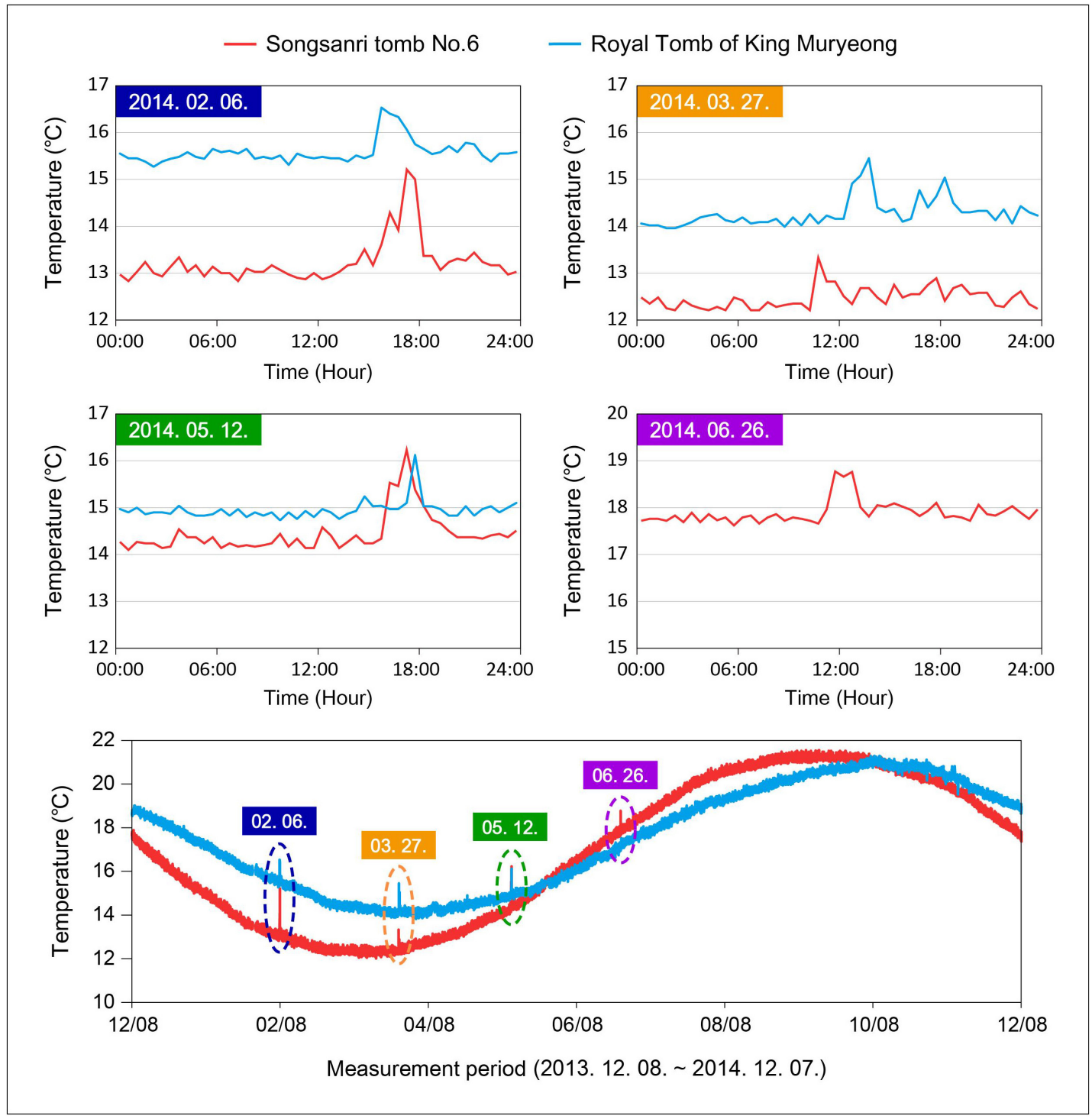

Figure 9. Temperature variations by artificial environment changes in tomb No. 6 and Royal Tomb of King Muryeong.

Table 12. Temperature distribution by entrance in tomb No. 6 and Royal Tomb of King Muryeong

\begin{tabular}{c|cccccccc}
\hline Classification & \multicolumn{4}{|c|}{ Tomb No.6 } & \multicolumn{3}{c}{ Royal Tomb of King Muryeong } \\
\hline Date & 02.06. & 03.27. & 05.12. & 06.26. & 02.06. & $03.27 .(1)$ & $03.27 .(2)$ & 05.12. \\
\hline Number of people & 4 & 3 & 3 & 2 & 4 & 3 & 2 & 3 \\
Time of stay (minute) & 90 & 20 & 90 & 40 & 30 & 50 & 60 & 20 \\
Increase of temperature $\left({ }^{\circ} \mathrm{C}\right)$ & 2.0 & 1.1 & 1.9 & 1.1 & 1.0 & 1.29 & 0.88 & 1.02 \\
\hline
\end{tabular}




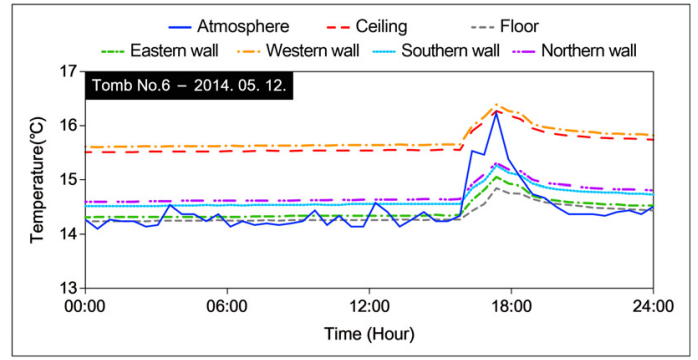

Figure 10. Temperature variations of all sensors by artificial environment change in tomb No. 6 .

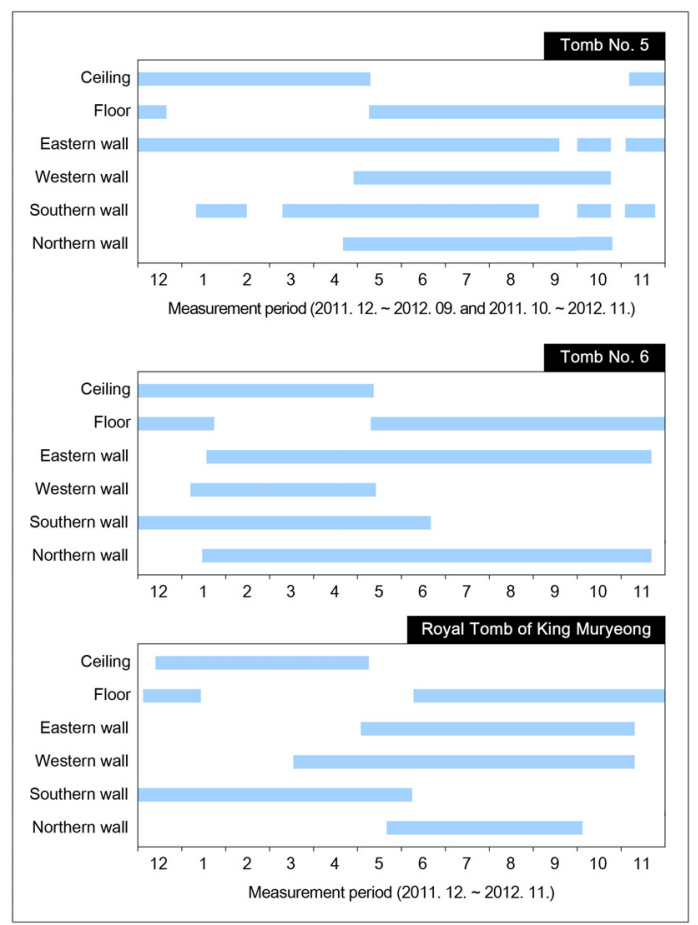

Figure. 11. Analytical results showing condensation condition of Royal Tombs at Songsanri.

(Figure 10). 이는 노점온도를 상승시켜 대기온도보다 낮은 벽체의 표면에 결로를 발생시킬 수 있다. 또한 출입자의 인 체에서 배출되는 수증기로 인해 절대습도가 증가하여 작은 온도변화에도 민감하게 반응할 수 있다. 따라서 연구목적 이라 하더라도 고분 내부로의 출입을 엄격히 제한해야 할 것으로 사료된다.

\subsection{5. 결로}

송산리 고분군에서 관찰되는 결로는 주로 벽체의 표면
에 수증기가 응결된 표면 결로로서 벽체의 표면온도가 노 점온도 이하일 때 형성된다. 결로는 고분의 벽체를 구성하 고 있는 부재와 6 호분 벽화의 손상에 직접적인 영향을 미 치므로 반드시 제어해야 한다. 이 연구에서는 1차 모니터 링 자료를 이용하여 고분군의 연간 결로 발생 조건을 분석 하였다. 특히 연중 포화상태를 유지하는 고분 내부는 현실의 기온이 노점온도이므로, 이를 천장, 바닥 및 벽체의 표면온 도와 각각 비교분석하여 결로 여부를 면밀히 검토하였다.

이 결과, 5 호분과 6 호분 및 무령왕릉 모두 연간 결로가 발생할 수 있는 조건으로 나타났다(Figure 11). 결로는 모 든 벽체의 표면에서 동시에 나타나지 않고, 위치와 시기에 서 차이를 보였다. 특히 천장과 바닥은 시기별로 상반되는 특징을 보였는데, 이는 계절변화에 따라 차별적으로 영향 을 미친 봉분의 축열과 현실 상하부의 온도차 때문에 나타 난 결과로 판단된다.

이를 고분별로 살펴보면, 큰 차이는 아니지만 무령왕릉 의 결로 발생 조건이 5 호분 및 6 호분보다 양호하게 나타난 것으로 보인다. 무령왕릉의 벽체는 5 호분의 동벽이나 6 호 분의 동벽 및 북벽과 같이 10 개월 이상 결로를 유지하는 조 건이 확인되지 않았다. 또한 5 호분과 6 호분은 천장과 바닥 면이 서로 교대하면서 연중 결로가 발생하나, 무령왕릉은 5 6월 사이에 결로가 발생하지 않는 조건을 보이면서 상이 하게 나타났다(Figure 11). 이와 같은 결로 조건이 형성된 이유는 일사 및 외기의 유입과 밀접한 관계가 있으며, 봉분 의 두께가 두꺼운 무령왕릉이 비교적 안정적인 결과가 나 타난 것으로 해석할 수 있다.

\section{4. 고찰 및 결언}

이 연구에서는 송산리 5 호분과 6 호분 및 무령왕릉의 미 기후 특성을 분석하고, 기상변화에 따른 보존환경의 안정 성을 해석하였다. 이 결과, 모든 고분의 현실은 연간 11.4 $22.2^{\circ} \mathrm{C}$ 의 온도분포를 보이며, $-16.9 \sim 52.4^{\circ} \mathrm{C}$ 의 변화폭을 보 인 외기상보다 계절변화의 영향이 횔씬 작은 것으로 나타 났다. 특히 무령왕릉의 현실은 최고기온이 $21.3^{\circ} \mathrm{C}$, 최저기 온이 $12.4^{\circ} \mathrm{C}$ 로 나타나며, 각각 $11.4 \sim 22.1^{\circ} \mathrm{C}$ 와 $11.8 \sim 22.2^{\circ} \mathrm{C}$ 의 온도범위를 보인 5 호분 및 6 호분 현실보다 안정적인 양 상을 나타냈다. 고분의 현실은 봉분의 축열로 인해 가을에 최고기온을, 봄에는 최저기온을 기록하였으며 외기상과 시 기적으로 두 달 정도의 시간차를 보였다.

송산리 고분군의 미기후는 대류로 인한 외기의 유입, 일 
사 및 바람 등의 기상변화와 사람의 출입에 따른 인위적 환 경변화의 영향을 받는 것으로 나타났다. 외기의 영향은 고 분 내부와 외부의 온도차가 커서 대류운동이 활발히 이루 어지는 여름과 겨울에 크게 일어나며, 출입문과 배수로를 통해 외기가 유입되는 6 호분이 가장 불안정한 온도분포를 보였다. 일사는 고분의 봉분 두께와 관련이 있으며, 현실에 서 봉토층까지의 연직거리가 긴 무령왕릉이 일사의 영향을 적게 받았다.

바람은 외부공기가 고분 내부로 유입되는데 가장 큰 역 할을 하는 환경인자로서 풍향이 고분의 출입문 방향과 일 치하고 풍속이 빠를 때 영향을 미치는 것으로 나타났다. 특 히 고분 내부에서 분리되어 있는 각 공간의 미기후 환경에 차별적인 영향을 미쳤으며, 이는 가장 복잡한 구조를 갖는 6 호분의 표준편차 분석결과를 통해 확인할 수 있다. 출입 문과 가까운 전실 $\mathrm{B}$ 와 전실 $\mathrm{A}$ 는 비교적 높은 표준편차를 보였고, 안쪽에 위치한 연도와 현실에서는 낮게 나타났다.

또한 사람이 고분 내부로 출입했을 때 일시적으로 불안 정한 대류가 형성되면서 미기후 환경이 변하였으며, 출입 인원 및 재실시간과 비례하였다. 인위적 환경변화는 현실 의 기온을 최대 $2.0^{\circ} \mathrm{C}$ 까지 상승시키기도 하였으나, 대부분 다시 하강하면서 안정화되었다. 특히 이 시점에는 현실의 대기온도 상승량이 천장, 바닥 및 각 벽면의 표면온도 상승 량보다 높게 나타났는데, 이는 노점온도를 상승시켜 벽면 의 결로를 유발할 수 있다. 따라서 고분 내부 출입을 엄격 히 제한해야 하며, 출입이 불가피한 경우에는 출입인원과 재실시간을 통제하여 고분군의 손상을 예방해야 할 것이 다. 특히 출입 시 인원은 3 명, 재실시간은 1 시간 이내로 제 한하고 사전에 방진복과 마스크 및 덧신을 착용 것이 바람 직할 것이다.

이 연구에서는 다양한 환경인자가 고분의 보존환경에 미치는 영향을 검토하기 위해 각 인자가 갖는 고유한 환경 적 특성이 뚜렷하게 나타난 시점의 자료를 집중 분석하였 다. 이에 따른 모든 분석결과가 특징적으로 나타나면서 환 경인자가 고분의 미기후 환경을 다소 교란시키고 있는 것 으로 해석되었으나, 실제로 모든 환경인자는 고분 내부에 서 단독적이지 않고 항상 복합적으로 작용하여 영향을 미 치고 있음을 고려해야 할 것이다.

한편 고분 내부는 고습한 환경으로 인해 벽체의 표면온 도가 노점온도 이상임에도 결로가 발생하고 있으며, 고분 을 폐쇄한 상태로 보존관리하고 있는 현재로서는 결로를 예방하기 힘들 것으로 보인다. 또한 봉분의 두께를 조절하 여 결로를 최소화할 수 있다 하더라도 봉분 조정은 고분의
구조안정성과 밀접한 연관이 있으므로 신중한 검토가 필요 하다. 여기에서는 따로 언급하지 않았으나, 여름철 집중강 우에는 빗물이 봉분으로 유입되면서 토양함수율이 증가하 였고, 이는 고분으로 작용하는 외력의 변화를 유발하여 벽 체의 이상거동을 초래하였다. 따라서 결로를 예방하기 위 해서는 현실의 기온을 낮출 수 있는 보다 안정적인 제어방 안이 마련되어야 한다.

이상의 결과를 종합하면, 송산리 고분군의 미기후는 다 양한 환경인자의 영향을 받는 것으로 나타났으나, 고분의 기밀상태는 매우 취약한 것으로 확인되었다. 각 고분 내부 는 공간의 분리와 외기의 유입을 효과적으로 차단하기 위 해 동판문과 철제문을 설치하였으나, 이는 대부분 노후 및 부식되어 기밀성이 감소한 상태이며, 원래의 기능을 상실 하였다. 이러한 요소는 기상변화나 대류현상을 통해 고분 으로 유입되는 외기의 양을 증가시켜 미기후 환경을 크게 교란시키고, 벽화의 손상을 가속화시킬 수 있다. 따라서 고 분군의 보존환경 개선을 위해 현실과 연도를 제외한 각 공 간 사이에 기밀성이 우수하고 단열성능이 좋은 소재로 창 호를 시공하였으며, 외부 출입문도 모두 교체하였다. 기밀 성 증가에 따른 송산리 고분군의 환경개선 효과도 상세히 보고할 예정이다.

\section{REFERENCES}

Ezcurra, P. and Rivera-Collazo, I.C., 2018, An assessment of the impacts of climate change on Puerto Rico's cultural heritage with a case study on sea-level rise. Journal of Cultural Heritage, 32, 198-209.

Jung, E.D., 2009, A study on the bronze spoons and chopsticks found from the tomb of King Muryeong. Prehistory and Ancient History, 30, 213-283. (in Korean with English abstract)

Jung, H.S., 2011, A study on the mural painting tomb of Baekje. The Journal of Korean Ancient History, 61, 301-336. (in Korean with English abstract)

Jung, S.K., 2012, A study on the Songsan-ri tombs, Gongju based on the data during the Japanese occupation of Korea. Journal of Central Institute of Cultural Heritage, 10, 249-292. (in Korean with English abstract)

Kim, D.W., Jeong, S.H., Lee, M.Y. and Chung, Y.J., 2016, Thermal environment analysis for preserving ancient mural painting in Songsan-ri tomb No. 6, Gongju, Korea. Journal 
of Conservation Science, 32, 521-534. (in Korean with English abstract)

Kim, J.Y. and Lee, C.H., 2010, Damage factor interpretation and conservational environment assessment by microclimatic analysis of Hyeonpung Seokbinggo(ice-storing stone warehouse), Korea. Journal of Conservation Science, 26, 385-395. (in Korean with English abstract)

Kongju National University, 2000, Conservational status of Songsanri Royal Tombs : The 2nd survey report of Songsanri Royal Tombs. 2-202. (in Korean)

Kongju National University, 2014, Research and development of eco-friendly air conditioning system for Royal Tombs at Songsanri, Gongju. 1-387. (in Korean)

Lee, J.H., 2017, Characteristics of the special patterned bricks of Songsan-ri tomb No. 6 and the accurate date of the tomb of King Muryeong. Society for the Study of Early Korean History, 27, 395-428. (in Korean with English abstract)

Lee, N.S., 2009, The values of Baekje's cultural relics as heritage in Gongju - A review for registering them as world heritage -. The Journal of Paekche Culture, 40, 185-202. (in Korean with English abstract)

Lee, S.M., Lee, C.H. and Kim, J.Y., 2010, Detailed deterioration evaluation and analysis of conservation environment for the Seosanmaaesamjonbulsang(rock-carved triad Buddha in
Seosan), Korea. Journal of Conservation Science, 26, 277-294. (in Korean with English abstract)

Martínez-Garrido, M.I., Ergenç, D. and Fort, R., 2016, Wireless monitoring to evaluate the effectiveness of roofing systems over archaeological sites. Sensors and Actuators A: Physical, 252, 120-133.

Masciotta, M.G., Ramos, L.F. and Lourenço, P.B., 2017, The importance of structural monitoring as a diagnosis and control tool in the restoration process of heritage structures: A case study in Portugal. Journal of Cultural Heritage, 27, 36-47.

Park, J.H. and Lee, C.H., 2018, Conservation status, construction type and stability considerations for fortress wall in Hongjuupseong(town wall) of Hongseong, Korea. Korean Journal of Cultural Heritage Studies, 51(3), 4-31. (in Korean with English abstract)

Suh, M.C., Lee, N.S., Choi, S.W., Kim, G.H., Jeong, S.M. and Lee, K.B., 1998, In-situ status and conservational strategy of the Muryong Royal Tomb, the Songsanri tomb No. 5 and the Songsanri tomb No. 6 of Baekje dynasty. The Journal of Natural Science, 7, 147-161. (in Korean with English abstract)

Yoon, Y.H., 2008, Sa-shin-do mural painting of No. 6 tomb in Kongju-Songsanri. The Journal for the Studies of Korean History, 33, 479-508. (in Korean with English abstract) 